\title{
Causes of mortality and morbidity in free- ranging mustelids in Switzerland: necropsy data from over 50 years of general health surveillance
}

\author{
E. Akdesir ${ }^{1}$, F. C. Origgi ${ }^{1}$, J. Wimmershoff ${ }^{1}$, J. Frey ${ }^{2}$, C. F. Frey ${ }^{3}$ and M.-P. Ryser-Degiorgis ${ }^{1 *}$ D
}

\begin{abstract}
Background: Although mustelids occur worldwide and include a wide range of species, little is known about the diseases affecting them. Mustelids have regularly been submitted for post mortem investigation in the framework of the program for general wildlife health surveillance in Switzerland, which has been in place for nearly 60 years. We performed a retrospective analysis of the necropsy reports on mustelids submitted to the diagnostic service of the University of Bern. The aims of this study were to present an overview of the causes of mortality and morbidity observed in these carnivores, to assess differences among species, to assess changes in disease detection over the study period, and to describe the pathology of selected diseases.
\end{abstract}

Results: Five hundred and sixty-six reports from 1958 to 2015 were analyzed. Most animals were stone martens (Martes foina, 46\%) and badgers (Meles meles, 44\%); the remaining species were polecats (Mustela putorius, 4.7\%), pine martens (Martes martes, 2\%), stoats (Mustela erminea, 1.4\%), weasels (Mustela nivalis, 0.8\%) and otters (Lutra lutra, 0.3\%). Infectious diseases $(n=262)$ were frequent and were mostly bacterial or viral; non-infectious conditions $(n=169)$ were less common and were mostly traumatic or due to metabolic disorders. The most frequent diagnoses included distemper (75\% were badgers), amyloidosis (96\% were martens), bacterial respiratory infections (all mustelids), biting lice (badgers only) and pulmonary and gastro-intestinal helminths (all species). Less frequent diseases included histoplasmosis (badgers only), aspergillosis, toxoplasmosis, hepatozoonosis, and sarcoptic mange. Lesions due to infection with distemper virus were primarily appreciated in the respiratory tract and central nervous system; they presented species-specific characteristics such as necrosis in the ependyma in badgers and absence of syncytia in stone martens. Amyloidosis in martens was multisystemic in most cases and included both AA and AL amyloidosis; the main macroscopic change was severe splenomegaly.

Conclusion: Infectious diseases were the most frequent causes of morbidity and mortality of mustelids, with marked species-specific differences. Lung and skin were the most commonly affected organs. Contagious diseases such as canine distemper, sarcoptic mange and rabies in mustelids showed a similar temporal pattern as in red foxes (Vulpes vulpes), suggesting pathogen spillovers from foxes to mustelids.

Keywords: Amyloidosis, Bacteria, Badger, Canine distemper, Histoplasmosis, Marten, Parasites, Pathology, Virus, Sarcoptic mange

\footnotetext{
* Correspondence: marie-pierre.ryser@vetsuisse.unibe.ch

${ }^{1}$ Centre for Fish and Wildlife Health (FIWI), Vetsuisse Faculty, University of

Bern, Länggassstrasse 122, Postfach, 3001 Bern, Switzerland

Full list of author information is available at the end of the article
}

(c) The Author(s). 2018 Open Access This article is distributed under the terms of the Creative Commons Attribution 4.0 International License (http://creativecommons.org/licenses/by/4.0/), which permits unrestricted use, distribution, and reproduction in any medium, provided you give appropriate credit to the original author(s) and the source, provide a link to the Creative Commons license, and indicate if changes were made. The Creative Commons Public Domain Dedication waiver (http://creativecommons.org/publicdomain/zero/1.0/) applies to the data made available in this article, unless otherwise stated. 


\section{Background}

Mustelids represent the largest family within the Carnivora order, consisting of 67 small to medium sized species with an elongated, slender body and short extremities (although there are some exceptions to this morphology). Mustelids occur worldwide, except in Australia and Antarctica [1, 2]. While some species are prolific and are considered pests because of the physical damage they cause to human property [3] or because of the pathogens they may carry $[4,5]$, others are experiencing population declines or are even listed as endangered [2].

The biology of a number of free-ranging mustelid species has been extensively studied but little is known about the causes of mortality in this family. Available data about diseases are generally limited to selected infections, such as bovine tuberculosis in the Eurasian badger (Meles meles) $[4,6,7]$, rabies in multiple species [5], or canine distemper [8-11] which has caused a severe population decline in black footed ferrets (Mustela nigripes) [12]. Aleutian disease has been investigated mostly in farmed mink (Neovison vison) but it may also be relevant to free-ranging mustelids such as the European mink (Mustela lutreola) [13-18]. Ectoparasites and endoparasites have been studied in free-ranging populations [19-23] but only rarely as causes of significant pathological lesions [24]. Reports on histoplasmosis in badgers and amyloidosis in martens (Martes spp.) are restricted to single cases or small case series [25-30]. A more recent study on stoats (Mustela erminea), weasels (Mustela nivalis) and polecats (Mustela putorius) presented data collected over 15 years but it was limited to respiratory disorders [31]. Thus, overviews on causes of mortality and morbidity in free-ranging mustelids are still lacking.

It has now been recognized that knowledge arising from general wildlife health surveillance is an important component of the One Health concept (i.e., the concept that the health of humans, animals and ecosystems is interconnected and that a coordinated, collaborative, multidisciplinary and cross-sectoral approach is required to address risks originating at the animal-human-ecosystems interface) [32-34]. General wildlife health surveillance is also recognized as being integral to wildlife conservation [35]. Carcasses of free-ranging wild animals submitted for necropsy in the framework of general surveillance are usually not representative for the whole population due to numerous factors influencing carcass submission. However, this type of surveillance delivers essential information on disease occurrence because pathological investigations are not restricted to the detection of selected causative agents but, as far as possible, document all disease processes affecting the animals investigated [36, 37]. Unfortunately, such information is only rarely published or publicly disseminated. Health surveillance, by definition, should not only include data collection but also data analysis and communication [37].

Mustelids can be found everywhere in Switzerland, but abundance, distribution and protection status vary among species. The Eurasian badger and stone marten (Martes foina) are common and can be hunted. The pine marten (Martes martes), stoat, weasel and polecat are much less abundant and have been protected species since 1978. The European fish otter (Lutra lutra) vanished from Switzerland in 1950; it has been protected by law since 1952 and a few individuals are now slowly recolonizing water streams in the midlands and the south-eastern part of the country [38]. A few ferrets (Mustela putorius furo) and American minks (Neovison vison) escaped from captivity in the past but have apparently not established free-ranging populations [1, 39, 40].

Wildlife health surveillance in Switzerland dates back to the 1950s. Several institutions have been involved in wildlife disease investigations but for the past two decades the majority of cases have been submitted to the Centre for Fish and Wildlife Health (FIWI) at the University of Bern, which is the national diagnostic laboratory for wildlife diseases [41]. Free-ranging mustelids have regularly been submitted for post mortem investigation since 1958.

This study aimed to increase the knowledge on causes of death and diseases of free-ranging European mustelids. Specifically, we wanted 1) to provide an overview of the causes of mortality and morbidity observed in free-ranging mustelids in Switzerland over half a century of general health surveillance; 2) to assess differences among species and potential changes in disease detection over time; and 3) to describe the pathological picture of selected diseases.

\section{Methods \\ Study area}

Switzerland $\left(41,285 \mathrm{~km}^{2}\right)$ is composed of 26 political units (cantons) of various sizes and three main bioregions: the Jura Mountains, shaped by forests and pastures; the highly urbanized Swiss Midlands; and the Alps, of which a large part is located above the timberline [42]. The Principality of Liechtenstein $\left(160 \mathrm{~km}^{2}\right)$ is adjacent to the eastern Swiss border and affiliated with the Swiss veterinary services (status similar to that of a canton). Depending on the hunting system of the canton, either hunters or officially appointed game wardens are in charge of wildlife health surveillance in the field [41, 43].

\section{Study material}

The study included all available necropsy reports of mustelids submitted to the wildlife group of the University of Bern (referred to as FIWI) from 1958 to 2015 (except the 
missing archive of 1960, 1969 and 1975-1977). There were 566 cases from seven species (badger, stone marten, pine marten, polecat, weasel, stoat and otter; Table 1) originating from 24 of the 26 Swiss cantons and from Liechtenstein.

Macroscopic examination was carried out either on whole carcasses $(n=550)$, or on single organs selected by the submitters $(n=16)$; histopathology was performed in most cases $(n=353)$. Tissue processing and staining methods were performed according to the standard protocols of the Institute of Animal Pathology of the University of Bern [43]. Additional diagnostic testing was conducted as indicated by case history and gross necropsy findings. In 490 cases at least one of the following additional examinations was performed: parasitology, bacteriology, virology and/or toxicology (Fig. 1). Laboratory protocols as well as completeness and accuracy of the necropsy reports varied throughout the study period due to administrative structural changes, personnel experience and technique availability [43].

Parasitological examinations $(n=300)$ included coprological analyses (flotation, sedimentation and Baermann-funnel; $n=271)$, digestion assay for Trichinella spp. $(n=41)$ [44], macroparasite identification (proglottids, helminth larvae and adults) [45, 46], and until 1992 washouts of gastrointestinal contents with subsequent sieving to retrieve parasites. Sarcoptic mange was diagnosed based on presentation of typical skin lesions together with the identification of intralesional Sarcoptes scabiei in affected skin samples. Light microscopy was used to examine skin scraping material and/or live mites isolated from skin specimens (by placing the skin specimen in petri dishes under a light source [47]). Mites were identified morphologically [48].

Virological analyses $(n=340)$ were performed for canine distemper virus (CDV) and rabies virus. Rabies testing was conducted at the Swiss Rabies Centre (Institute of Veterinary Virology, University of Bern) by immunofluorescence

Table 1 Free-ranging mustelids submitted to the FIWI for pathological examination, Switzerland, 1958-2015

\begin{tabular}{|c|c|c|c|c|c|c|c|c|c|c|}
\hline \multirow[t]{2}{*}{ Species } & \multirow[t]{2}{*}{ Total } & \multicolumn{3}{|c|}{ Adult } & \multicolumn{3}{|c|}{ Young } & \multicolumn{3}{|c|}{ Unknown age } \\
\hline & & $\mathrm{F}$ & M & $U$ & $\mathrm{~F}$ & M & $U$ & $\mathrm{~F}$ & M & U \\
\hline Badger & 249 & 73 & 86 & 5 & 21 & 31 & 3 & 14 & 11 & 2 \\
\hline Stone marten & 262 & 62 & 99 & 2 & 29 & 25 & 4 & 11 & 18 & 9 \\
\hline Pine marten & 13 & 4 & 4 & 1 & 1 & 0 & 0 & 0 & 2 & 1 \\
\hline Polecat & 27 & 4 & 8 & 0 & 5 & 4 & 3 & 1 & 2 & 0 \\
\hline Stoat & 8 & 1 & 3 & 0 & 1 & 2 & 0 & 0 & 1 & 0 \\
\hline Weasel & 5 & 0 & 0 & 0 & 1 & 0 & 0 & 1 & 2 & 1 \\
\hline Otter & 2 & 1 & 1 & 0 & 0 & 0 & 0 & 0 & 0 & 0 \\
\hline Total & 566 & 145 & 201 & 8 & 58 & 62 & 10 & 27 & 36 & 13 \\
\hline
\end{tabular}

$F$ Female, $M$ Male, $U$ Unknown

Young: juveniles and subadults

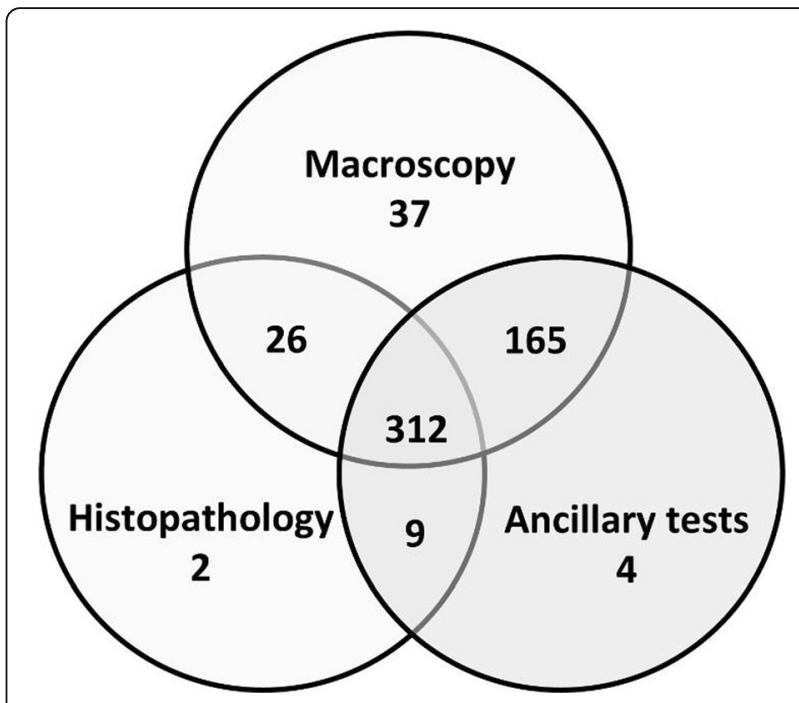

Fig. 1 Investigations performed on the free-ranging mustelids submitted to the FIWI, Switzerland, 1958 to 2015. Ancillary tests: bacteriological, virological, parasitological and/or toxicological analyses

assay (IFA). At the time of the rabies epidemic (1967 to 1997), cases suspicious for rabies were submitted directly to the Swiss Rabies Centre. Positive cases were not forwarded to the FIWI for analysis and were therefore not included in this study. Until 1992, CDV testing was also performed by IFA at the Institute of Veterinary Virology of the University of Bern. From 1993 onwards, immunohistochemistry (IHC, $n=42$ ) [49] was used to test for CDV; from 2010 onwards this was increasingly replaced by polymerase chain reaction (PCR; $n=29)$ [10].

Bacteriological analyses $(n=300)$ were carried out using standard cultivation and identification by biochemical strips (API $20 \mathrm{E} / \mathrm{NE}$ ) and more recently by Matrix-Assisted Laser Desorption Ionization - Time Of Flight (MALDI-TOF). Fungi were cultured on Sabouraud-Dextrose Agar [43]. Histoplasma capsulatum was presumptively diagnosed based on characteristic morphological features on histology [50]. Samples from four badgers from areas at risk for bovine tuberculosis were tested by PCR for the presence of mycobacteria of the Mycobacterium tuberculosis complex at the Swiss national reference laboratory for tuberculosis (Institute for Veterinary Bacteriology, University of Zurich) according to established protocols [51]. Of these four badgers, one animal from the canton of Grisons, 2010, presented with multiple purulent skin wounds; and three badgers from the canton of Fribourg were culled for targeted testing in 2013 and were apparently healthy.

Toxicological examinations were documented in four cases with suspected poisoning (two martens examined in 1958 and 1991; a stoat examined in 1989; and a badger examined in 1990). Unfortunately, documentation did not specify either the laboratory or the analytic methods. 


\section{Data management}

Animal data, case history (in particular the mention of behavioral changes such as aggression or fearlessness in the presence of people or domestic animals, apathy and diurnal activity), submitted material, submitter details, results of investigations and name of the investigators were digitalized in an Excel table (Microsoft Excel 2010, Microsoft Corporation, Redmond, Washington, USA). Martens without species specification (Martes sp., $n=15$ ) were counted as stone martens because this is the most common marten species in Switzerland and often simply referred to as "marten".

Animals were classified as either young (including animals mentioned as either juvenile or subadult on the reports) or adult. In absence of age information $(n=102)$, age was estimated $(n=31)$ by comparing available animal data (body weight, condition, sex, season, age) with those of other submitted cases of known age groups and with published reference values $[1,52]$. When data were insufficient, the age group remained unknown $(n=71)$. Seasons referred to calendar months (winter: January-March; spring: April-June; summer: July-September; Fall: October-December).

Maps were drawn with the free software QGIS 2.8 Wien [53] using the submitted $(n=120)$ or estimated $(n=400)$ coordinates. Coordinates were estimated using the location information provided by the submitter and the website of the Federal Office for Swiss Topography [54]. Forty-six cases with insufficient location information were not mapped.

The "main diagnosis" was defined as the most likely cause of death (if the animal was found dead) or as the most likely cause of the clinical signs that had motivated the culling of the animal. Main diagnoses were classified based on etiology. Additional findings were recorded separately but categorized according to the same scheme as the main diagnoses $[43,55]$.

\section{Retrospective investigations on canine distemper}

Histopathological changes consistent with canine distemper (CD; interstitial pneumonia or inflammation of the central nervous system [10]) were mentioned in the necropsy report of 25 out of 45 cases with reported abnormal behavior but without etiological diagnosis and without mention of CDV testing. Based on the availability of archival paraffin blocks and tissue preservation, 10 of these 25 cases were later selected to be tested for CDV by PCR. They included six cases from 1993 and one case each from 1997, 1998, 2000, and 2005. RNA-extraction from paraffin blocks, RT-PCR and gel electrophoresis steps were performed as previously described [10]. Additionally, sections of brain and lung tissues of cases confirmed as CDV positive either by PCR or IHC ( $n=45$, from 1999 to 2015) were evaluated based on previously published criteria [10] with some additions.

To assess differences in disease detection and pathological features, two time periods were distinguished, namely before and after the large distemper epidemic that hit Switzerland in 2009 and subsequently expanded over the country from east to west, affecting mainly red foxes [10].

\section{Retrospective investigations on amyloidosis}

Tissue sections of spleen and kidneys from eight martens affected by amyloidosis for which archival material was available were stained with Congo red (with and without potassium permanganate pre-treatment) and examined for birefringence under polarized light to determine the type of amyloid deposits. Amyloidosis was classified as AA amyloidosis in absence of birefringence and as non-AA amyloidosis in presence of birefringence following potassium permanganate pre-treatment $[30,56]$.

\section{Statistical analyses}

Differences among species, age groups, seasons and study periods in our investigation material were assessed using either the chi-square test or the two-tailed Fisher's exact test. The tests were run with NCSS 2001 software (Hintze, J., 2001; NCSS, Kaysville, Utah, USA [57]). Level of significance was set at $P<0.05$.

\section{Results}

\section{Submitted material}

The submitted species included mainly stone martens (46\%) and badgers (44\%); a few polecats $(4.7 \%)$, pine martens $(2 \%)$, stoats $(1.4 \%)$ and weasels $(0.8 \%)$; and two otters $(0.3 \%$; Table 1$)$. Adults were more numerous than young animals in all species, except for the polecat in which both groups were equal. There were generally more males than females (53 and $41 \%$ of all animals, respectively).

Case numbers were significantly higher in spring $(n=206)$ and summer $(n=209)$ than in autumn $(n=91 ; P<0.001)$ and winter $(n=57 ; P<0.001)$ in all species. Besides a marked peak of cases in $1993(n=188,33 \%)$, yearly case numbers varied from 2 to 28 (Fig. 2) with a mean of about eight animals per year. Nearly half of the submissions originated from the canton of Bern (45\%) but the number of cases per hectare was the highest in the canton of Basel-Stadt (30 cases/ha, 13 cases), followed by Basel-Landschaft ( 4 cases/ha, 24 cases) and Bern (4 cases/ha, 247 cases; Fig. 3). In terms of bioregions, the number of submissions was lowest from the Alps.

Submission was mostly from official game keepers (55\%), although cases were also submitted by the general public (24\%), veterinarians (8\%) and the police (4\%). Behavioral change was the most common reason for the 
animals to be culled (60\% of all culled cases), followed by fur and skin changes (7\%). No history was indicated for the other cases.

\section{Overview of the main causes of mortality and morbidity}

An overview of the main diagnoses is presented in Table 2. Infections were more common (46\%) than non-infectious conditions (30\%) in all species. The most common infectious conditions were CD in badgers (18\% of the submitted badgers) and bacterial infections in martens ( $16 \%$ of the submitted martens), followed by parasitic (4\%) and fungal diseases (1\%). Infections were followed by trauma $(18 \%)$, amyloidosis in martens $(10 \%$ of the submitted martens), and occasional neoplasia and intoxications (both $<1 \%$ ). There was no conclusive etiological diagnosis for 150 cases (27\% of all submissions), including 75 cases of suspected infectious etiology. These were mainly martens and badgers, a few polecats, one weasel and one stoat with bronchopneumonia or interstitial pneumonia $(n=29)$, and/or myocarditis $(n=17)$ and/or hepatitis $(n=13)$ and/or nephritis $(n=10)$ and/or inflammation of the central nervous system (CNS; $n=16)$. All of the animals included in this study that were tested for rabies virus were negative.

The high number of cases submitted in 1993 included mainly culled animals ( $n=109: 72$ martens, 31 badgers, 6 polecats), of which at least 49 cases (45\%) were culled due to abnormal behavior (no information available for the others). Main diagnoses in these animals were bacterial infections $(n=42,22 \%$ of all cases from 1993), amyloidosis in 26 martens ( $14 \%$ of all cases from 1993) and trauma ( $n=56,30 \%$ of all cases from 1993).

\section{Canine distemper}

There was a total of $60 \mathrm{CD}$ cases (Table 2), diagnosed by IHC $(n=26)$, PCR $(n=17)$ and/or histology. The death of these animals was always considered directly related to this disease, whether they had been found dead or shot. Shooting was mostly related to behavioral changes such as apathy and daylight activity and, especially in martens, aggression and fearlessness in presence of humans or domestic animals. Animals of both sexes and
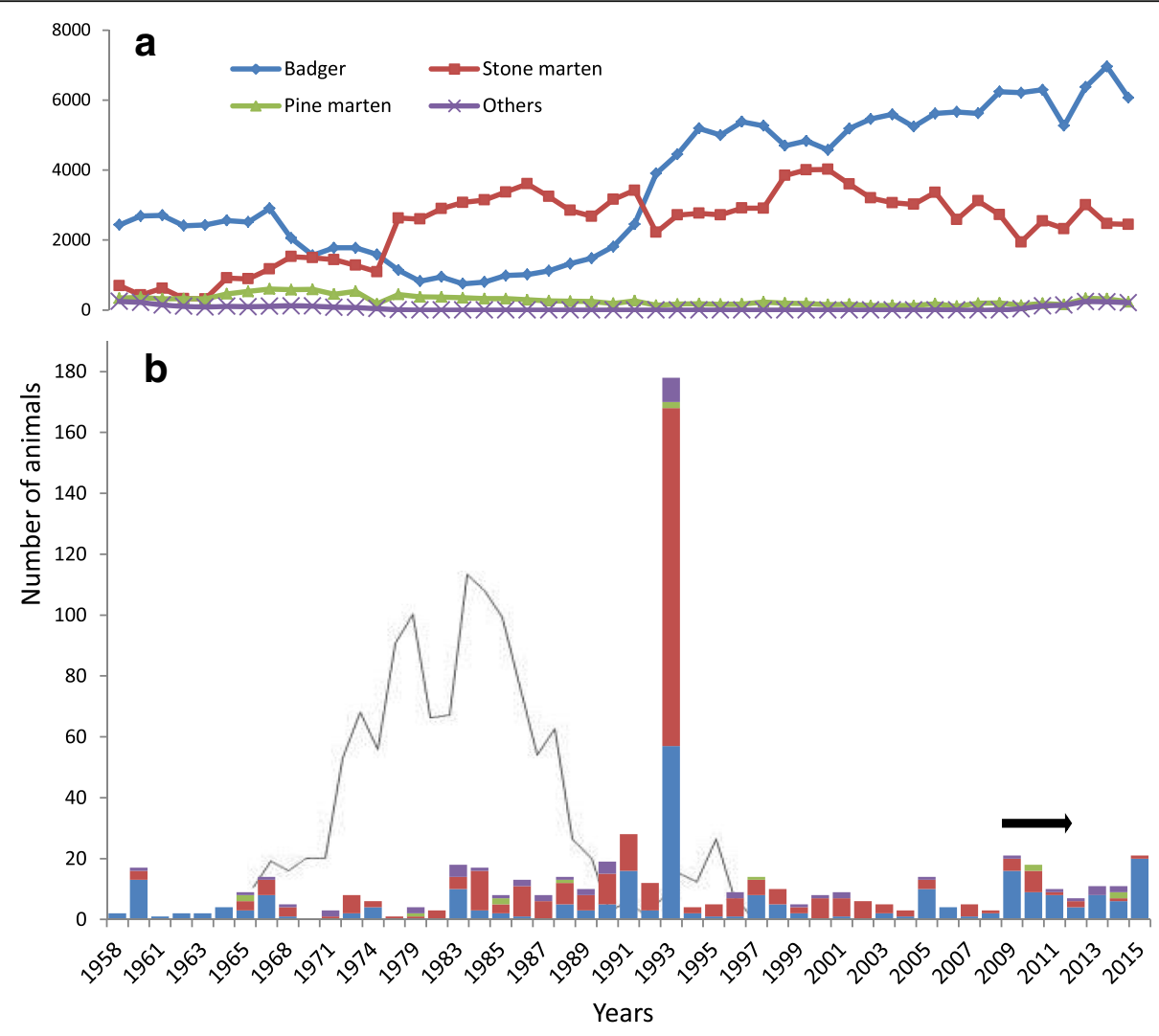

Fig. 2 Free-ranging mustelids found dead, culled or hunted in Switzerland from 1958 to 2015. Diagram a shows the total number of dead mustelids, including those shot and found dead, which were recorded in Switzerland from 1958 to the winter 2014/15 (national hunting statistics). Diagram b shows the number of cases submitted to the FIWI from 1958 to 2015 (animals included in the present study), using the same color code for different mustelid species as in Diagram a. The black line in Diagram b represents the number of mustelids diagnosed positive for rabies at the Swiss Rabies Center. Rabies investigations began in 1967 and cases were recorded until 1997, when the disease was eradicated from Switzerland. The horizontal black arrow indicates the years of the national epidemic of canine distemper 


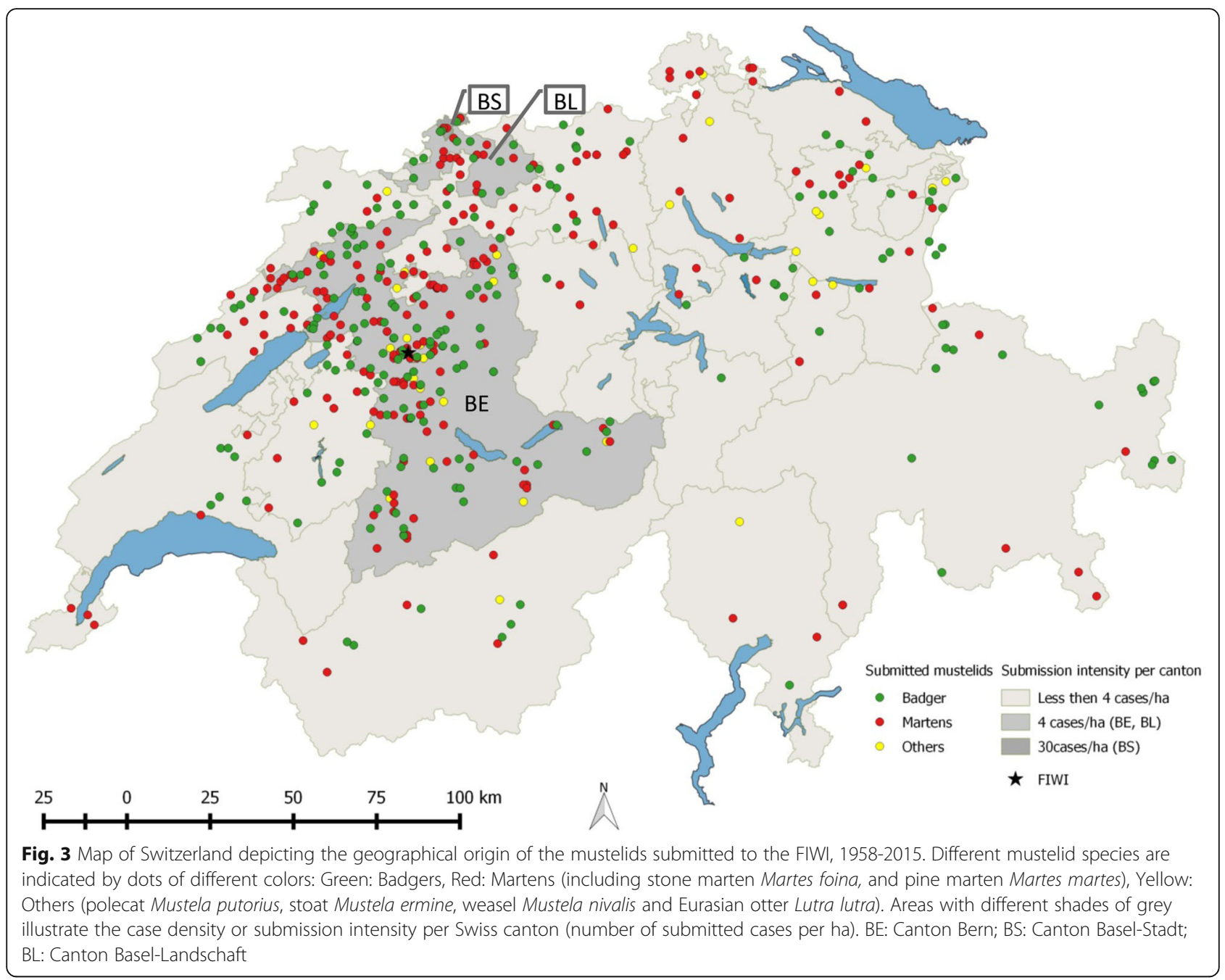

age categories were affected, without significant differences between these groups.

The majority of CD cases (76\%) were diagnosed from 2009 onwards. They included 41 out of $45 \mathrm{CD}$ cases documented in badgers (91\%) and 4 out of 11 cases in martens $(27 \%)$. This corresponded to a significant increase of the percentage of cases affected by CD in both species: Before 2009, CD was diagnosed in only $2 \%$ of the submitted badgers and 3\% of the martens, while since $2009 \mathrm{CD}$ was found in $60 \%$ of the badgers and $27 \%$ of the martens $(P<0.001$ and $P=0.016$, respectively). From 2009, CD cases in badgers showed a spatial progression from the easternmost part of the country at the border to Liechtenstein and Austria to the west, south-west and north. By contrast, no specific spatiotemporal pattern was observed for $\mathrm{CD}$ cases in martens.

Macroscopic lesions associated with CD frequently included patchy areas of dark red mottling in the lungs (70\%) and rarely conjunctivitis with mucopurulent ocular discharge $(5 \%)$ or hyperkeratosis of the foot pads (one badger and one marten). Animals affected by $\mathrm{CD}$ were often emaciated $(41 \%)$ and had no or very little gastrointestinal content. Histologically, the most commonly affected organ systems were the respiratory tract (RT) and CNS, with lesions mostly in both of them $(n=31,51 \%)$, less commonly in the RT only $(n=26$, $43 \%)$, and rarely in the CNS only $(n=4,6 \%)$. Lesions were characterized by lymphoplasmacytic to histiocytic inflammation in the lungs and CNS (Table 3, Fig. 4a-d). Additionally, hepatic inflammation including hepatitis, cholangio-hepatitis and cholangitis was observed in eight cases (six badgers and two martens from different years). Characteristic intranuclear and/or intracytoplasmic inclusions were reported in 36 cases $(60 \%$, including badgers, martens and polecat). Inclusions were found in the bronchiolar, urinary, biliary and gastric epithelial cells in all species, and additionally in ependymal epithelium ( $n=6$, Fig. 4c) and in seminiferous tubules $(n=1)$ in badgers only, and in corneal epithelium and epidermis in one marten each. Syncytia were regularly 
Table 2 Main etiological diagnoses documented in free-ranging mustelids necropsied at the FIWI, Switzerland, 1958-2015

\begin{tabular}{|c|c|c|c|c|c|}
\hline & $\begin{array}{l}\text { Badgers } \\
n=249\end{array}$ & $\begin{array}{l}\text { Martens }^{a} \\
n=275\end{array}$ & $\begin{array}{l}\text { Others }^{b} \\
n=42\end{array}$ & $\begin{array}{l}\text { Total } \\
n=566\end{array}$ & $\% 100$ \\
\hline INFECTIOUS & 97 & 66 & 13 & 261 & 46 \\
\hline \multicolumn{6}{|l|}{ Viral } \\
\hline Distemper virus & 45 & 14 & 1 & 60 & 11 \\
\hline \multicolumn{6}{|l|}{ Bacterial } \\
\hline Streptococcus sp. ${ }^{c}$ & 15 & 15 & 2 & 32 & 6 \\
\hline Escherichia sp. & 5 & 9 & 2 & 16 & 3 \\
\hline Staphylococcus sp. & - & 5 & - & 5 & 1 \\
\hline Other bacteria & $13^{d}$ & $14^{\mathrm{d}, \mathrm{e}}$ & $6^{f}$ & 33 & 6 \\
\hline \multicolumn{6}{|l|}{ Fungal } \\
\hline $\begin{array}{l}\text { Histoplasma } \\
\text { capsulatum }\end{array}$ & 4 & - & - & 4 & 1 \\
\hline Aspergillus sp. & - & 1 & - & 1 & - \\
\hline \multicolumn{6}{|l|}{ Parasitic } \\
\hline Pulmonary parasites & 4 & 3 & 2 & 9 & 2 \\
\hline $\begin{array}{l}\text { Gastro-intestinal } \\
\text { parasites }\end{array}$ & 10 & - & - & 10 & 2 \\
\hline Sarcoptes scabiei & 1 & 5 & - & 6 & 1 \\
\hline NON-INFECTIOUS & 49 & 84 & 7 & 170 & 30 \\
\hline \multicolumn{6}{|l|}{ Trauma } \\
\hline Blunt & 30 & 40 & 3 & 73 & 13 \\
\hline Point (bite) & 12 & 8 & 1 & 21 & 4 \\
\hline Nonspecified & - & 5 & 3 & 8 & 1 \\
\hline Amyloidosis & 1 & 27 & - & 28 & 5 \\
\hline Neoplasia & 1 & 2 & - & 3 & 1 \\
\hline Intoxication ${ }^{9}$ & 1 & 1 & - & 2 & - \\
\hline Other non-infectious ${ }^{h}$ & 4 & 1 & - & 5 & 1 \\
\hline OTHER & 49 & 63 & 19 & 167 & 29 \\
\hline Undetermined ${ }^{i}$ & 3 & 43 & 16 & 98 & 17 \\
\hline Non-diagnostic & 36 & 13 & 3 & 52 & 9 \\
\hline Apparently healthy & $10^{k}$ & $7^{1}$ & - & 17 & 3 \\
\hline
\end{tabular}

${ }^{\mathrm{a} S t o n e}$ and pine marten. ${ }^{\mathrm{b}}$ Polecat, otter, weasel. ${ }^{\mathrm{C}}$ S. canis, S. dysgalagtiae sp. S. equisimilis. ${ }^{d}$ Mixed bacterial infection. ${ }^{e}$ Pasteurella sp., Klebsiella sp., Aeromonas sp., Francisella tularensis. ${ }^{f}$ Mycobacterium sp., Pasteurella sp. ${ }^{9}$ Benzidin and arsenic intoxication. ${ }^{\text {h}}$ Myocardial calcification in two badgers, hypertrophic cardiomyopathy in a marten and fatty liver changes in two badgers. Includes four badgers, 18 martens, a polecat and a stoat suspected to have viral infections and 11 badgers, nine martens and three polecats suspected to have bacterial infections. Insufficient material quality. ${ }^{k}$ One (1972) and three (1993) badgers of unknown history, three badgers for mange monitoring (2005) and three badgers for targeted testing for Mycobacterium bovis. 'Martens caught in traps without specified purpose $(n=6)$ or sent for mange monitoring despite the lack of visible fur changes $(n=1)$

observed in badgers (in the lung and more occasionally in the brain, Fig. 4d) but only in one stone marten (urinary bladder, Table 3). The histopathological descriptions of the cases for which archival material was not available (cases before 2009 and seven badgers after 2009) were consistent with our own observations in the newly assessed cases.
Additional infections were reported in $17 \%$ of all CD cases and included toxoplasmosis $(n=4)$, streptococcosis $(n=2)$, and one case each of actinomycosis, candidiasis, adiosporomycosis, histoplasmosis and hepatozoonosis. Although there were few cases, toxoplasmosis was diagnosed at a significantly higher proportion among CD cases $(4 / 60,6.7 \%)$ than in the other animals included in this study $(2 / 506,0.4 \% ; P=0.002)$.

\section{Bacterial infections}

Bacterial infections were common main diagnoses both in martens and in badgers (15 and 13\% of all submitted animals per species, respectively) and suspected in 23 additional cases. Whether as a main diagnosis $(n=105)$ or as an additional finding $(n=19)$, confirmed bacterial infections affected mainly the RT in all species $(n=54$, $32 \%$ of all bacterial infections); infections were associated with lesions consisting of bronchopneumonia or interstitial pneumonia, and, rarely, with pleuritis and pyothorax $(n=5)$. Other affected organs were the heart ( $n=37,22 \%)$, kidney $(n=20,19 \%)$, liver $(n=14,13 \%)$, CNS $(n=8,7 \%)$ and skin $(n=5,4 \%)$.

Streptococcus sp. was the most frequent $(\mathrm{n}=19,35 \%)$ isolate in all bacterial RT infections. Ten of 14 badgers (71\%) and ten of 20 martens (50\%) with Streptococcus sp. infection had old skin wounds suspected to have been the portal of entry for the bacteria. Severe, but not specific lesions associated with Francisella tularensis in a stone marten (Table 2) have been described in detail elsewhere [58].

Bacterial infections that were not considered to play a role in the main disease process were relatively few $(n=19)$; they comprised a similar spectrum of organisms as observed for the main diagnoses. They included unspecified Streptococcus sp. (two badgers, three martens), mixed flora (four badgers, two martens, one polecat), Escherichia coli, Staphylococcus sp. and Actinomyces (one badger each), Salmonella sp. (one stoat) and Clostridium welchii (one stone marten). In three cases bacterial species remained undetermined (no growth in culture or bacteria detection at histology). In these 19 animals, the main diagnoses included trauma, CD, histoplasmosis, Mesocestoides sp. infection, lymphoma, amyloidosis.

\section{Fungal diseases}

Mycoses were rarely diagnosed $(n=11)$. Except for four cases of histoplasmosis and one case of aspergillosis (Table 2), they were considered additional findings. Altogether there were six cases of histoplasmosis, a disease which was diagnosed only in badgers. These badgers consisted of five adults (four males, one female) and one juvenile male; they were submitted from various geographical locations and during different years. One of them was also affected by CD. They all had dermatitis, 
Table 3 Histopathological lesions associated with canine distemper virus infection in free-ranging mustelids, Switzerland, 1958-2015

\begin{tabular}{|c|c|c|c|c|c|c|c|c|c|}
\hline & \multicolumn{6}{|l|}{ CNS } & \multirow{2}{*}{$\begin{array}{l}\text { Lung } \\
\text { INT/BINT }\end{array}$} & \multirow{2}{*}{$\begin{array}{l}\text { Syncytia } \\
\text { L/B }\end{array}$} & \multirow{2}{*}{$\begin{array}{l}\text { Inclusions } \\
\text { B/L/O }\end{array}$} \\
\hline & Gliosis & Meningitis & Encephalitis & NN & Gray/Both ${ }^{a}$ & $\overline{\text { Ependyma }}$ & & & \\
\hline Badger $(n=41)$ & $33(80 \%)$ & $21(51 \%)$ & $28(68 \%)$ & $8(19 \%)$ & $16 / 20$ & $14(34 \%)$ & $11 / 28$ & $16 / 4$ & $9 / 24 / 7^{b}$ \\
\hline Stone marten $(n=3)$ & 3 & 2 & 2 & 0 & $0 / 3$ & 0 & $3 / 0$ & $0^{c}$ & $4 / 3 / 2^{d}$ \\
\hline Pine marten $(n=2)$ & 2 & 1 & 1 & 0 & $1 / 1$ & 1 & $0 / 2$ & 0 & $1 / 0 / 0$ \\
\hline
\end{tabular}

CNS Central nervous system, NN Neuronal necrosis, INT Interstitial pneumonia, BINT Bronchointerstitial pneumonia, $L$ Lung, $B$ Brain, $O$ Other organs

aPart of the neuropil affected by the inflammatory process: Gray: gray matter, Both: gray and white matter. ${ }^{\text {bin }}$ the epithelial cells of the bile ducts $(n=2)$, urinary bladder $(n=4)$, stomach $(n=2)$ and seminiferous tubules $(n=1)$. ${ }^{~ S y n c y t i a ~ f o r m a t i o n ~ i n ~ o n e ~ c a s e ~ i n ~ t h e ~ u r i n a r y ~ e p i t h e l i u m . ~}{ }^{d}$ In the corneal epithelium $(n=1)$ and epidermis $(n=1)$

usually suspected to be sarcoptic mange by the submitter. In two badgers the subcutaneous lymph nodes and the lungs were also affected. Lesions were characterized by firm, raised and ulcerated skin nodules associated with hair loss. Similar nodules were also seen in the lungs (Fig. 5a, b). Histologically, the nodules were determined to be granulomas with intralesional fungal elements observed either in the cytoplasm of histiocytes or extracellularly. These organisms were round to oval, $5 \mu \mathrm{m}$ in diameter, with a $2 \mu \mathrm{m}$ thick wall, a $2 \mu \mathrm{m}$ diameter peripherally located round nucleus, and characterized by narrow-based budding (Fig. 5b, d) and morphologically identified as $H$. capsulatum. Macrophages and multinucleated cells, mostly of Langhans type, were the dominant inflammatory cells, followed by lymphocytes and neutrophils.
Other fungal diseases included aspergillosis (in two martens, a badger and a polecat), characterized by granulomatous pneumonia with intralesional fungi, and pharyngeal candidiasis (one badger), characterized by suppurative pharyngitis and tonsillitis with intralesional yeasts.

\section{Ectoparasites}

Nineteen animals (three martens and 16 badgers) were submitted with a suspicion of sarcoptic mange, which was confirmed in only four of them. Mange was additionally observed in two martens with a different history. Overall, S. scabiei was detected in three stone martens (in 2005, 2009 and 2010), two pine martens and a badger (all three from 2014; Table 4). They were all adult animals originating from different geographical locations. In martens, mange was characterized by diffuse

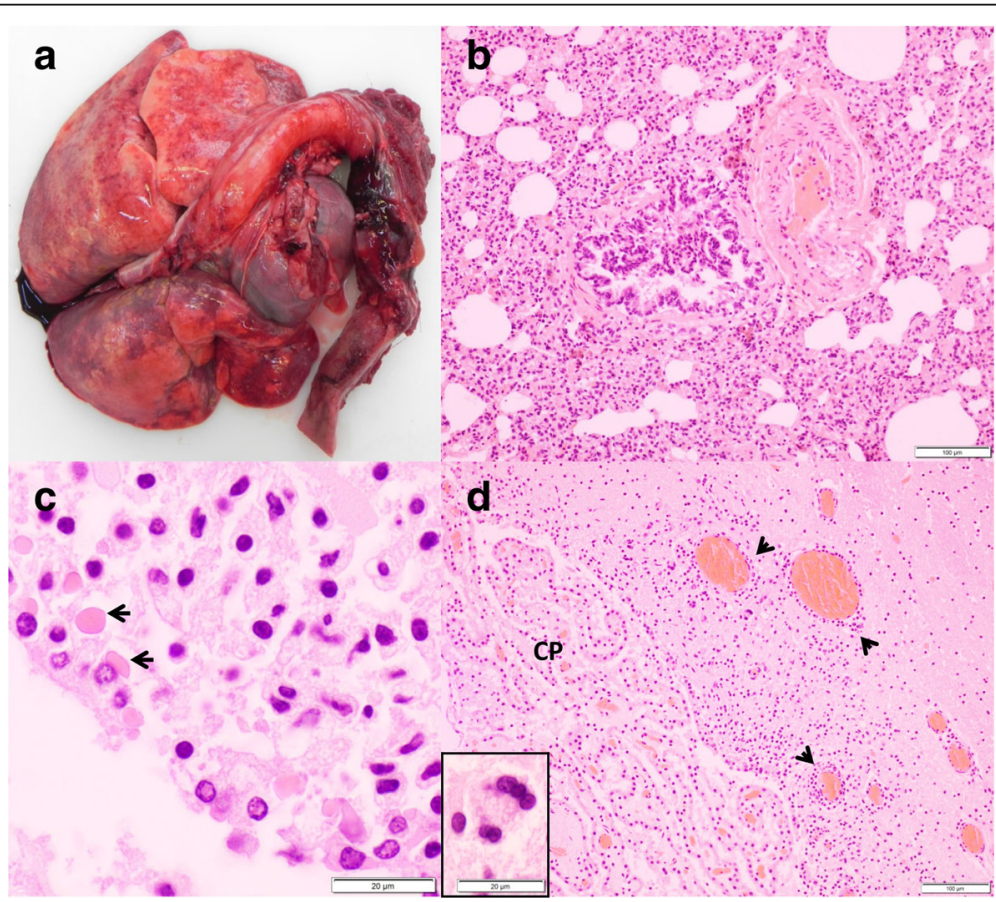

Fig. 4 Lesions associated with canine distemper virus infection in badgers. a Lungs with "wet-like" appearance, which are not collapsed and display multifocal red to dark red mottling. b Lung section, H\&E stain: Severe interstitial pneumonia. c Brain section, H\&E stain: Intracytoplasmic, eosinophilic inclusions (arrows) in the ependymal epithelium. $\mathbf{d}$ Brain section of the same animal, H\&E stain: Multifocal, lymphoplasmacytic perivascular cuffs (arrow heads) and neuronal syncytia (inset), choroid plexus (CP) 


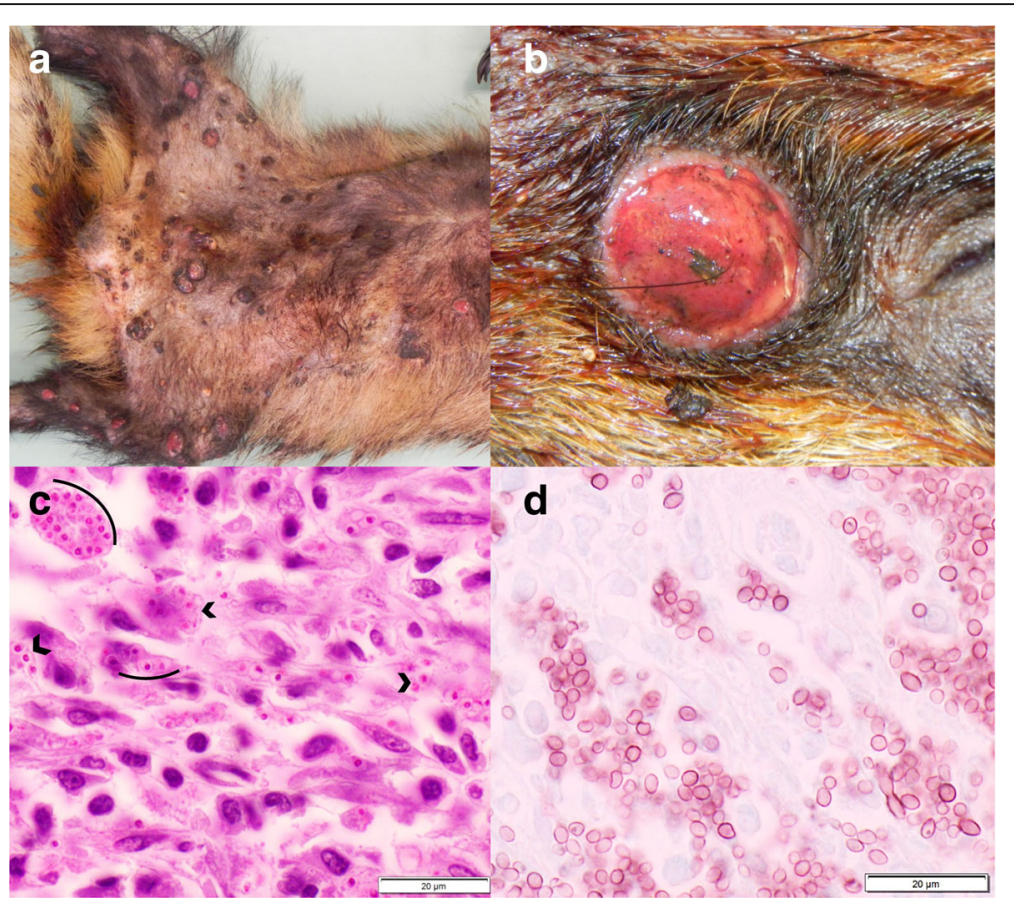

Fig. 5 Skin lesions associated with Histoplasma capsulatum infection in badgers. a Multiple, well-demarcated, ulcerated nodules disseminated on the ventral aspect of the body. $\mathbf{b}$ Close-up of a nodule. $\mathbf{c}$ Histological section of a nodule, PAS stain: Numerous round-oval, 1-3 $\mu$ m diameter yeasts consistent with Histoplasma capsulatum (arches). d Histological section of a nodule, Grocott stain: Detailed morphology of Histoplasma capsulatum with evident narrow-based budding

crusty skin lesions and hair loss on the dorsal aspect of the body, including the ears, back, tail and occasionally also the flanks, and/or extremities (Fig. 6a). Microscopically there was exuberant hyperkeratosis with cellular debris and bacteria trapped into the thickened keratin, along with moderate epidermal hyperplasia (Fig. 6b). Large numbers of mites were embedded in the crusts or found in the epidermis and rarely the dermis, with moderate to mild infiltration of neutrophils, lymphocytes and plasma cells, and very few mast cells in the superficial dermis. The only badger diagnosed with mange presented with a different picture: Skin lesions were also located on the dorsal aspect of the body but were characterized by hair rarefaction and skin reddening with only minimal crusts on the nose, lumbo-sacral area and lateral thighs. Microscopically there was moderate hyperkeratosis, epidermal hyperplasia and a few mites on the epidermis, with abundant lymphoplasmacytic to histiocytic infiltrations in the dermis; very few eosinophils and mast cells were appreciated.

Of a total of 16 badgers with alopecic lesions, 11 (69\%) were infested by biting lice and/or ticks (Fig. 7a, Table 4). In these cases, alopecia was especially prominent on the ventral aspect of the body. By contrast, lice were never reported in martens. Focal alopecia and/or crust formation were typically attributed to mange by the submitters, but these lesions sometimes resulted from bite wounds, which were another common cause of skin lesions both in badgers $(n=20)$ and martens $(n=26)$. In one badger with bite wounds and severe lice infestation, histological examination revealed the presence of mites consistent with Demodex sp. in association with pustular dermatitis.

\section{Endoparasites}

The exact number of mustelids for which a parasitological examination was conducted was unclear and semi-quantitative data were mostly lacking, but endoparasites were mentioned in 239 (42\%) of the submitted cases. The reported parasites consisted mainly of helminths detected in the digestive tract (124 cases or $81 \%$ of all mustelids with gastrointestinal parasites) and/or in the lungs (96 cases or $97 \%$ of all mustelids with pulmonary parasites, Fig. $7 \mathrm{~b}-\mathrm{d}$ ). Intestinal protozoans (mainly Isospora sp.) were repeatedly found in badgers but were uncommon in martens (Table 4). The intestinal cestode Oochoristica incisa (Syn: Atriotaenia incisa) was mentioned 15 times in badgers until 1992 but it was not found in other mustelid species and was not mentioned in later years anymore. Rarely observed lung or gastro-intestinal parasites included Aelurostrongylus sp., Euryhelmis squamula and Cryptosporidium sp., which were reported only in badgers (Table 4). 
Table 4 Parasites recorded in free-ranging mustelids necropsied at the FIWI, Switzerland, 1958-2015

\begin{tabular}{|c|c|c|c|}
\hline & Badgers & Martens ${ }^{a}$ & Others $^{\mathrm{b}}$ \\
\hline \multicolumn{4}{|l|}{ ENDOPARASITES } \\
\hline \multicolumn{4}{|l|}{ Pulmonary ${ }^{c}$} \\
\hline Eucoleus sp. & 17 & 7 & - \\
\hline Crenosoma sp. & 7 & 6 & 6 \\
\hline Filaroides sp. & 14 & 8 & 4 \\
\hline Aelurostrongylus sp. & 2 & - & - \\
\hline Angiostrogylus sp. & 1 & - & - \\
\hline \multicolumn{4}{|l|}{ Gastrointestinal $^{d}$} \\
\hline \multicolumn{4}{|l|}{ Nematodes } \\
\hline Capillaria sp. & 15 & 35 & 2 \\
\hline Uncinaria sp. & 9 & 5 & 1 \\
\hline Ascarids & 2 & - & 1 \\
\hline Trichostrongylids & 3 & 5 & 4 \\
\hline Cestodes & 39 & 18 & 2 \\
\hline Atriotaenia incisa & 15 & - & - \\
\hline Taenia sp. & 6 & 13 & 1 \\
\hline \multicolumn{4}{|l|}{ Trematodes } \\
\hline Euryhelmis squamula & 2 & - & - \\
\hline \multicolumn{4}{|l|}{$\underline{\text { Protozoa }}$} \\
\hline Isospora sp. ${ }^{e}$ & 24 & 3 & - \\
\hline Eimeria sp. & 1 & - & 1 \\
\hline Cryptosporidium sp. & 1 & - & - \\
\hline \multicolumn{4}{|l|}{ Muscular } \\
\hline Trichinella sp. & - & 2 & - \\
\hline Sarcocystis sp. & 1 & 1 & - \\
\hline Hepatozoon sp. & 1 & 3 & - \\
\hline Alaria sp. & - & 1 & - \\
\hline \multicolumn{4}{|l|}{ Multisystemic } \\
\hline Toxoplasma gondiif & 1 & 3 & 1 \\
\hline Mesocestoides sp. & 1 & 1 & - \\
\hline \multicolumn{4}{|l|}{ ECTOPARASITES } \\
\hline Ticks (Ixodes sp.) & 15 & 8 & 4 \\
\hline Fleas (Paraceras sp.) & 5 & 7 & 1 \\
\hline Lice (Trichodectes sp.) & 45 & - & 1 \\
\hline \multicolumn{4}{|l|}{ Mites } \\
\hline Sarcoptes scabiei ${ }^{9}$ & 1 & 5 & - \\
\hline Demodex sp. & 1 & - & - \\
\hline
\end{tabular}

Parasites detected either at macroscopic pathological examination or by coprology. Since the exact number of analyses is not known for the different parasites, no percentage was indicated. ${ }^{\mathrm{a}}$ Stone and pine marten. ${ }^{\mathrm{b}}$ Polecat, otter, weasel. ' Clinically relevant in four badgers, three martens and two polecats. ${ }^{d}$ Clinically relevant in 10 badgers. "Identified as I. melis (six badgers), I. mustelae and I. lacazei (three and one marten, respectively). ${ }^{f}$ Clinically relevant in a marten and a polecat. ${ }^{9}$ All clinically relevant
Gastro-intestinal parasites were reported to be associated with a local inflammatory reaction, mostly lymphoplasmacytic to eosinophilic, in only $10 \%$ of the infected animals. Lungworms were reported to be associated with a local inflammation in $75 \%$ of the cases, which consisted mostly of lymphoplasmacytic to histiocytic inflammatory reaction and increased alveolar macrophages. Lesions associated with Filaroides sp., one of the more commonly mentioned lungworms in mustelids, were characterized by nodules of $5-10 \mathrm{~mm}$ in diameter containing numerous tightly whorled, gray to green nematodes (Fig. 7d).

Other parasites were located intramuscularly (cardiac and skeletal musculature) and included Hepatozoon sp. (in three martens, associated with mild granulomatous myocarditis; and a badger with $\mathrm{CD}$, without Hepatozoon sp.-associated inflammation), Trichinella sp., Alaria sp., and Sarcocystis sp. in martens (one case each) without inflammation. Toxoplasma gondii cysts were found histopathologically in brain or lung of four martens and a badger and in multiple organs of a polecat, of which three martens and the badger had CD. Although very rarely mentioned $(n=2)$, larval Mesocestoides sp. was abundant in one marten with numerous parasite cysts in the abdomen and thorax with mild lymphohistiocytic serositis. In one polecat, unilateral bone penetration in the infraorbital region suggested Troglotrema sp. infestation but the parasite itself was not detected.

\section{Amyloidosis}

Amyloidosis was a frequent non-infectious condition observed in this study (57 cases) and it affected martens $(55 / 275,20 \%)$ significantly more often than badgers $(2 / 249,1 \% ; P<0.001)$. Amyloidosis has been regularly reported since 1965 , either as a main diagnosis (Table 2) or as an additional finding. It was detected more frequently in adults $(44 / 172,26 \%)$ than juveniles $(4 / 55$, $7 \% ; P=0.004)$. There was no difference between sexes $(31 / 106$ or $29 \%$ adult males vs. $13 / 66$ or $20 \%$ adult females; $P=0.209$ ). In martens, amyloidosis was frequently the main pathological process, without any predisposing chronic inflammation $(n=32,58 \%$ of all marten cases with amyloidosis). Bacterial infections and endo-/ectoparasitism were significantly less frequent in martens with amyloidosis than martens without it ( $42 \%$ vs. $89 \% ; P<0.001$ ). One of the two badgers with amyloidosis had $\mathrm{CD}$ but the other case presented with only an intestinal Isospora melis infection without associated lesions.

Amyloidosis was multisystemic in most cases (66\%), although the spleen was most commonly affected (94\%), followed by lesions in the kidneys (45\%), liver (42\%), heart (24\%) and mesenterial lymph nodes (one marten). 


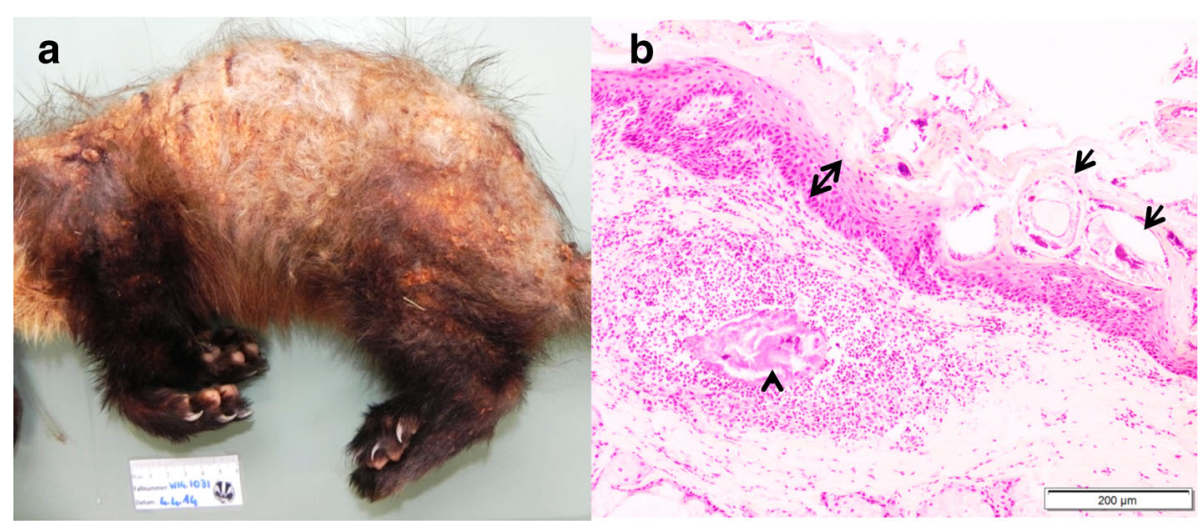

Fig. 6 Skin lesions associated with Sarcoptes scabiei in martens. a Pine marten: Hair loss and skin crust formation affecting mainly the dorsal aspect of the body. b Stone marten, histological section (H\&E stain): Mites (arrows) embedded in sero-cellular crusts on the hyperplastic epidermis (double headed arrow). Remnants of a mite (arrow head) in the dermis with focal, suppurative dermatitis and dermal edema

Macroscopically, lesions were splenomegaly together with a rubber-like consistency (Fig. 8a and b), and a slight enlargement of the kidneys rarely in combination with pallor and petechiae (Fig. 8c). Histologically, deposits of a homogenous, eosinophilic, glassy material (amyloid) were found perivascularly in the spleen (Fig. 8d, e); in the basement membrane of the glomerular tufts, Bowman's capsule and less commonly in the renal tubules (Fig. 8f); within the spaces of Disse and portal areas of the liver; within the heart valves; and perivascularly in several other organs. The brain was investigated in four martens but no lesions were detected.

The retrospective evaluation of tissue sections of eight martens revealed non-AA amyloidosis in five cases and AA-amyloidosis in three.

\section{Other lesions of non-infectious origin}

Traumas were most common in adult animals $(74 \%$ of all traumas) both in badgers $(n=44 ; 29 \%$ of all adult badgers) and martens ( $n=51 ; 20 \%$ of all adult martens).

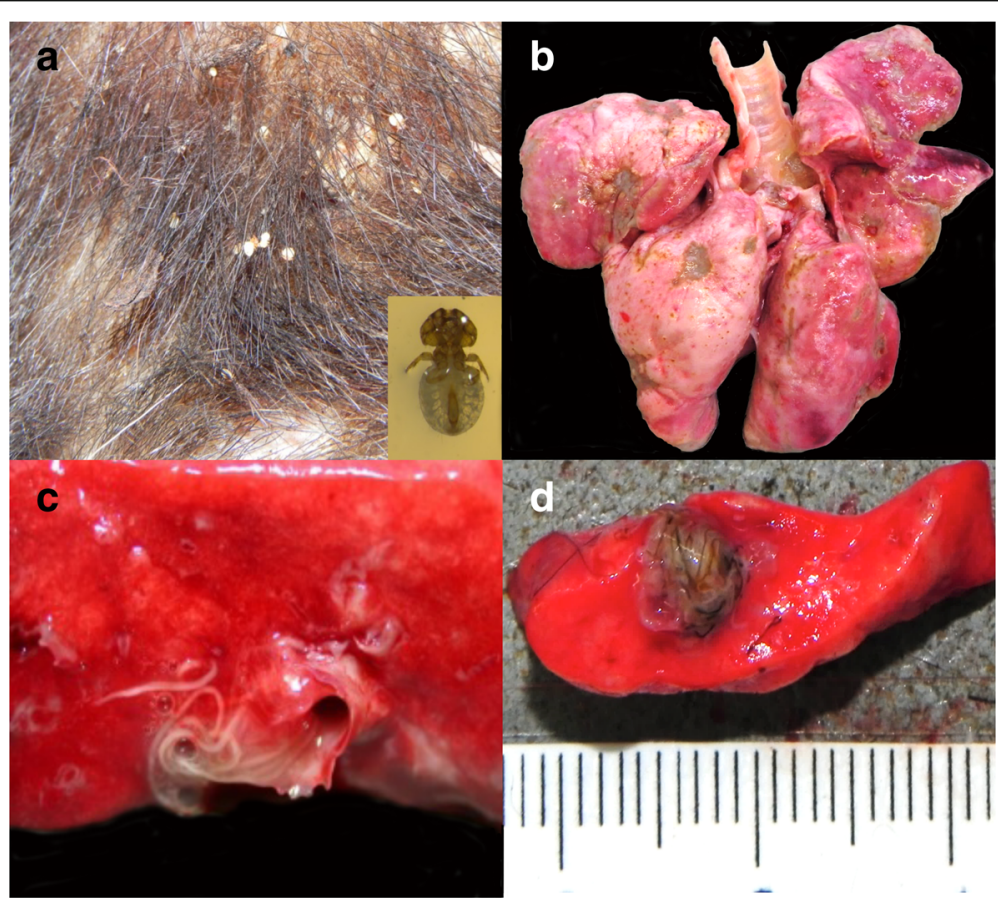

Fig. 7 Common ecto- and endoparasitism in free-ranging mustelids from Switzerland. a Close-up of the skin of a badger with severe Trichodectes melis infestation with hair loss and crust formation. A close up of T. melis is shown in the inset. $\mathbf{b}$ Lungs of a badger with multifocal, light tan to gray indented areas associated with Crenosoma sp. c Cut surface of the lungs of a badger with numerous intrabronchial lungworms, Crenosoma vulpis. $\mathbf{d}$ Cut surface of a polecat's lung with a cluster of lungworms, Filaroides sp. 


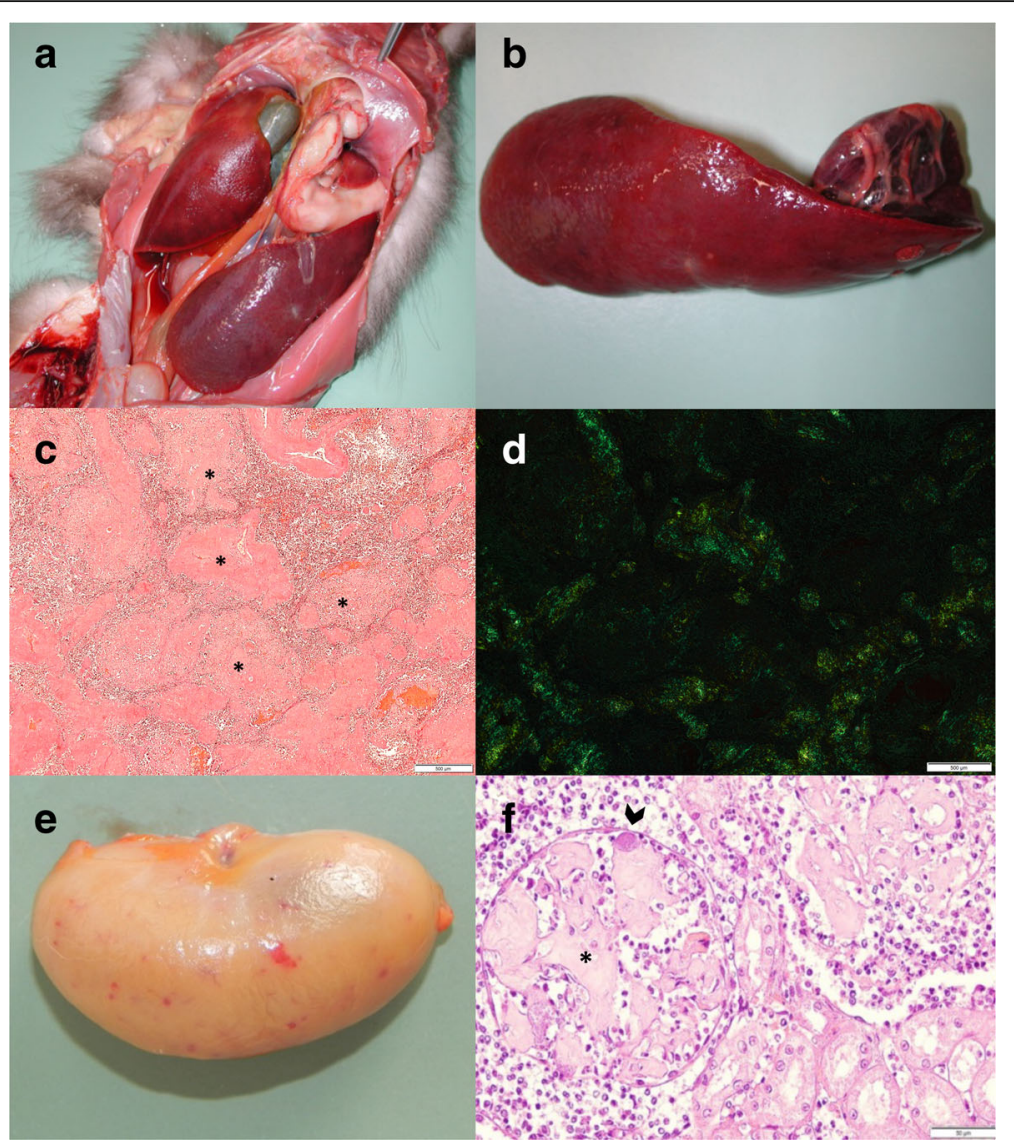

Fig. 8 Lesions associated with amyloidosis in martens. a Pine marten, abdominal organs in situ: Severely enlarged spleen. b Same pine marten as in a, extracted spleen: Severe splenomegaly, increased consistency and rubber-like texture. c) Stone marten, Congo red stain, spleen: Severe deposition of amyloid (asterisk) around the blood vessels. $\mathbf{d}$ Same stone marten as c, Congo red stain, spleen: Apple-green birefringence under polarized light. e Pine marten, kidney: Diffuse tan discoloration with petechial hemorrhages. $\mathbf{f}$ Stone marten, histological section of a kidney (H\&E stain): The glomeruli are partially obstructed by abundant deposit of eosinophilic, fibrillary material consistent with amyloid (asterisk) and a bacterial embolus within the lumen of the glomerular capillary (arrow head)

Blunt traumas variably affected the head, thorax, or hind limbs. Bite wounds were mostly found in the frontal part of the body including neck, ears and shoulders (66\%), and at the base of the tail (18\%).

Neoplastic conditions were of major clinical relevance in only three cases, including lymphoma in a badger and stone marten and non-specified abdominal masses in a pine marten (Table 2). Other neoplasms were classified as side pathological processes and included a non-specified benign ovarian tumor, a dermal hemangioma and a pulmonary mesenchymal tumor in badgers (one case each) and non-specified masses in the liver and spleen in martens (one case each).

Tooth wear, and missing or broken teeth, were repeatedly reported in adult badgers $(n=19)$, once in association with severe osteomyelitis of the mandible. Pneumoconiosis was also observed multiple times and mainly in badgers (25 badgers and three martens) throughout the years 1964 to 2015.

\section{Discussion}

Our study provides a first overview of diseases and causes of death diagnosed in free-ranging mustelids in a continental European country. The number of submitted cases represents a minor portion of the dead mustelids recorded by the Swiss hunting authorities $(<0.3 \%$ of the carcasses have been submitted for analysis per year in the past 20 years) (Fig. 2). However, the species representation in our study generally reflected their occurrence and abundance in the wild, with the exception of stoats. Stoats were submitted less frequently than polecats although stoats are more abundant than polecats in Switzerland [59]. The proportionally very low number of stoats might be related to their small body size, as carcasses of small wildlife species are less likely to be detected $[60,61]$. However, in a similar study conducted in Great Britain [31], stoats were proportionally more numerous than polecats in the submitted material. This suggests that other factors must influence the detection 
and submission of stoat carcasses, such as their likelihood to be found in the environment or the public interest for these animals.

Cases originated from all parts of the country, but predominantly from the canton of Bern and neighboring regions (Fig. 3) located in relatively close proximity to the FIWI. Nevertheless, considering that mustelids can easily be shipped by regular mail thanks to their small body size, the geographical proximity alone does not explain this bias. The uneven distribution of cases is likely due to the fact that not all Swiss cantons have a long tradition of wildlife health surveillance and that until the 1990s most wild animals found in western Switzerland were submitted to another laboratory [41, 43]. The higher numbers of cases submitted from the canton of Basel-Stadt and Basel-Landschaft (Fig. 3) were mainly martens. These two cantons have the highest (Basel-Stadt: 5072 inhabitants $/ \mathrm{km}^{2}$ ) and fourth highest human density (Basel-Landschaft: 502 inhabitants $/ \mathrm{km}^{2}$ ) of all Swiss cantons. Stone martens are known as "culture chasers" due to their ability to take advantage of human infrastructure, such as deserted buildings, roof floors and bridges that they use as shelter [62-64]. Therefore, in such an environment, dead martens and/or animals observed with disease signs such as abnormal behavior or skin lesions are more likely to be found, and the incentive for submission to a laboratory may be higher due to the fear of pathogen transmission to domestic pets or humans.

Behavioral change was indeed the most common reason for case submission. Rabies was frequently diagnosed in mustelids as well as in other carnivores by the Swiss Rabies Center from 1967 until eradication in 1997 (Fig. 2) [65, 66], and many of the mustelids submitted for necropsy at the FIWI [this study] were diagnosed with either $\mathrm{CD}$ or amyloidosis. Rabies and CD are well known to be associated with behavioral changes, and amyloidosis has also been reported to be associated with aggression and fearlessness in martens [52].

The case load per year was relatively stable (Fig. 2), except for the marked peak in 1993, which was most likely related to the increased awareness of the public due to the rabies control efforts in Switzerland in the early 1990s. Despite a history of abnormal behavior, neither rabies nor $\mathrm{CD}$ was diagnosed in any of these cases. Causes of mortality included mainly bacterial infections, blunt trauma and amyloidosis, in proportions comparable to those obtained for the whole study period. Regarding the unclear cases with suspected CD lesions that were retrospectively tested by PCR, degradation of the RNA in the old paraffin blocks may have impaired the detection of CDV.

Given that the majority of submitted samples were adults, this study delivers mostly data for this age group.
The low number of juveniles may be due to a lower likelihood of being detected due to their smaller body size and/or to their denning behavior from birth in early spring to dispersion in mid-autumn [67]. Similarly, higher numbers of cases in spring and summer might be associated with a higher mortality rate related to a higher biological activity of mustelids during this period of the year [68]. Such an increase in case observations in the spring was indeed previously observed in badgers with bovine tuberculosis [4].

In the majority of our cases, the main diagnosis was of infectious origin. This contradicts another retrospective study on mustelids by Simpson et al. [31] and the national hunting statistics [69]. This difference is likely due to the fact that animals found dead in the field with a clear picture of trauma such as a car collision are generally not submitted for post mortem investigation in Switzerland and are therefore underrepresented in our material. By contrast, Simpson et al. [31] specifically collected animals killed in traffic accidents or trapped in the framework of a pest control program to conduct their study. Nevertheless, trauma remained the most common non-infectious cause of death in our study, and bite wounds were suspected to have played a role in infectious disease cases by causing a port of entry for opportunistic bacteria.

The data available for this study were collected in the framework of routine examinations, i.e., investigations were not done systematically according to a predetermined protocol but were question-oriented. However, macroscopic examinations were performed according to institute standards, and histology and ancillary tests were frequently performed. Only selected organs were submitted for less than $3 \%$ of the animals. Overall, it seems unlikely that major information on the cause of mortality and morbidity of the submitted animals would have been lost in relation to the study design.

\section{Canine distemper}

Distemper is a well-known disease in mustelids [8-11, $70,71]$, and since the eradication of rabies it has become the main viral disease affecting mustelids in Switzerland. The emergence and distribution of badger cases from 2009 onwards indicates a relationship with the national epidemic in the red fox, as also shown by molecular analyses in Switzerland and other countries [10, 72-74]. By contrast, the situation in martens is less clear. A link between the fox epidemic and marten cases after 2009 seems likely, considering that the virus was found in other hosts during this period, including a free-ranging lynx (Lynx lynx), a domestic dog (Canis familiaris) [10], a domestic cat (Felis catus) [75] and captive Asian marmots (Marmota caudata) [76]. However, CD was present in stone martens in Switzerland before this 
epidemic [63; this study] and there were similarities between the older and recent strains [10], suggesting that martens might play a role as reservoir of $C D$ virus. Nevertheless, the more common occurrence of CD cases in badgers compared to martens might be related to different risks of intraspecies transmission due to different social systems, as badgers live in social groups whereas martens are solitary animals [68].

The pathological picture of $\mathrm{CD}$ in our study animals corresponds to former reports of CD in mustelids [10, 70]. Differences among histological lesions in red fox, badgers and martens were previously pointed out [10], however, this observation was based on the examination of only eight badgers and three martens. Here we confirmed the existence of species-specific differences: Periventricular and ependymal CNS lesions were found only in badgers and syncytia formation in brain and lung were not found in martens, which might suggest a different host-related pathogenesis of the disease [10, 77]. Concurrent diseases like toxoplasmosis and secondary bacterial infections might have been favored by CDV-induced immunosuppression [78, 79]. However, since this situation concerned only a minority of cases in our study and these diseases were also found in CDV-negative animals, concurrent infections may have been purely incidental.

\section{Bacterial infections}

Bacterial infections were mostly associated with pulmonary or cutaneous disorders and typically involved Streptococcus and/or Staphylococcus species. These bacteria were reported as the most common pyogenic bacteria in mustelids [52] and are known to be associated with dermatitis, respiratory infection, inflammation in several organs and septicemia in various animal species [52, 70, 80, 81]. In our study, many animals with bacterial infections had skin wounds. Since Streptococcus sp. and Staphylococcus sp. belong to the mucosal microflora [82], the skin wounds were suspected as a portal of entry for the bacteria, as previously suggested for martens [52], otters [83] and foxes. Other less common bacterial pathogens like Pasteurella sp. [31, 84], Klebsiella sp., Clostridium sp. and Francisella tularensis [84] were detected in our study in agreement with previous reports.

The typical inflammatory pattern associated with aerogenic bacterial infections in the lungs is bronchopneumonia [85]. However, in our study several animals with bacterial infections had an interstitial pneumonia. This might be due to a primary or concomitant viral infection, or to a vascular spread of the bacteria from another portal of entry (such as a skin wound) to the pulmonary interstitium, rather than a primary lung infection through inhalation. Finally, frequent occurrence of bacterial bronchopneumonia with concomitant lungworm infection suggests that tissue damage by lungworms may predispose to bacterial infection [86].

Infections with Mycobacterium bovis are frequent in Eurasian badgers in several countries. In the United Kingdom, badgers have played a role as a reservoir for $M$. bovis for decades $[4,6,87]$ and there is some concern that this species could maintain M. bovis in other countries such as France or Spain $[88,89]$. Bovine tuberculosis (bTB) has re-emerged in Europe, including countries surrounding Switzerland [90, 91], but none of the causative agents ( $M$. bovis and $M$. caprae) has been identified in Swiss wildlife since the country was declared officially free of bTB in 1960 [90]. Switzerland has been repeatedly mentioned as the first country with bTB diagnosis in a badger but these statements relied on an incorrect citation of an old article reporting a bTB case in an Alpine chamois (Rupicapra rupicapra rupicapra) in 1951 [92]. Although targeted investigations have not been performed in badgers so far, to our knowledge, bTB has never been diagnosed in badgers in Switzerland.

\section{Skin lesions}

The second most frequent reason for submission after abnormal behavior was skin changes, mostly assumed to be mange by the submitter. Since 2002, the FIWI has run a nationwide monitoring program for sarcoptic mange [93] and actively asked field partners to submit all wild mammals showing mange-like lesions for analysis. However, mange was diagnosed in only a few mustelids. Skin lesions were mostly related to other causes like infected bite wounds, histoplasmosis, and severe lice or flea infestation.

Sarcoptic mange is a contagious skin disease affecting numerous mammal species and typically associated with high mortality in wildlife [94]. In Switzerland, it has been present for several decades in wild carnivores, progressively expanding all over the country. It kills mainly foxes [95] and occasionally other species such as the Eurasian lynx [96] and martens (this study), all showing severe crusty lesions consistent with the fatal form of the disease [95]. Despite the many badgers with skin lesions that were examined for mites, S. scabiei was detected in only one badger in our material. Previous studies $[32,97,98]$ have also pointed at the rarity of sarcoptic mange in badgers. The pathological picture in the single badger found infested with mites was largely consistent with the alopecic form of mange in the healing phase, except for the presence of a few mites in the lesions [95]. Overall, the rare occurrence of mange cases in badgers and the mild signs recorded in this affected individual suggest that badgers are less susceptible to $S$. scabiei than other carnivores. This is also supported by the comparison of the number of mange and $C D$ cases 
among foxes, lynx, martens and badgers during the past ten years, when these two contagious diseases became widespread in carnivores in Switzerland: Cases were numerous in foxes and low in martens and lynx, but in all three species there was a similar proportion of mange and CD cases [FIWI unpublished data, this study], hinting at a comparable spread and clinical impact of the two causative agents in these hosts. By contrast, in badgers the proportion of mange was very low compared to $\mathrm{CD}$.

In contrast to putative sarcoptic mange susceptibility, badgers were commonly infested with biting lice, while these ectoparasites were not noticed in martens. Lice were repeatedly associated with alopecia in badgers, and it is conceivable that pruritic licking and scratching causes these skin changes. Indeed, alopecia associated with lice was typically distributed on the ventral aspect, where the parasite is commonly found, as opposed to the dorsal lesions characterizing sarcoptic mange.

Histoplasmosis was diagnosed only in badgers, with a pathological picture corresponding to previous reports in this species $[25-28,50]$. Histoplasma capsulatum occurs in soil contaminated with bird and bat droppings and is known to affect mainly dogs but also many other mammals, including humans [50,99]. Susceptibility of the badger to this zoonotic disease was proposed to be related to their omnivorous nature [100] or to selective immunodeficiency due to evolutionary and immune system development [26].

Bite wounds were repeatedly observed both in martens and badgers and identified as the primary cause of skin lesions such as post-scarring alopecia. Bite wounds are common in mustelids [83, 101-103] and may be related to intraspecific fights, especially in martens. In mustelids there is a correlation between the degree of intra-sexual territoriality (associated with aggressive behavior) and the degree of body elongation, sexual dimorphism and degree of carnivorous behavior [104], three characteristics which are more pronounced in martens than in badgers.

\section{Endoparasites}

A wide range of endoparasites was documented in this study. Part of these were previously reported in badgers, martens, polecats and/or minks, including gastrointestinal parasites such as Isospora sp., Eimeria sp., Uncinaria sp., Taenia sp., Capillaria sp. and Euryhelmis squamula [19-22, 105-107], muscle parasites like Trichinella sp. [108-110], Alaria sp. [111] Hepatozoon sp. [24] and Sarcocystis sp. [112], and systemic parasites like T. gondii [113]. Larval infection with Mesocestoides sp. is known to be of zoonotic importance as it has been reported in humans [114], dogs and other canids [115], and in badgers and martens [52, 111]. Oochoristica incisa (Syn. Atriotaenia incisa) was also previously described as a common enteral cestode in badgers [20,
116] but it was not reported in the necropsy reports of the FIWI after 1992. This is likely a bias due to a change in investigation techniques, because after 1992 gastrointestinal contents was no longer routinely washed out and sieved to retrieve adult parasites. Similarly, widespread gastro-intestinal helminths of roe deer were no longer documented at the FIWI in the past two decades [43]. Furthermore, eggs of trichostrongylid-type (not further identified) that were found in this study could indicate the sporadic presence of non-mustelid specific parasite stages (Table 4). Possible shedding of ingested parasite stages should be taken into account when performing coprological analyses for endoparasites of carnivores [117]. Lungworms have been repeatedly reported in mustelids $[19,21,23,31]$, with mostly the same species as in our study, including Capillaria aerophila (Syn. Eucoleus aerophilus), Crenosoma, Filaroides and Aelurostrongylus species. By contrast, Skrjabingylus sp. was reported in various European countries [21, 31, 118-120] but was not detected in the mustelids present in this study. Skrjabingylus sp. is a parasite of the nasal cavity, a body localization that is rarely examined, and it may have been missed during routine examination. Angiostrongylus sp. was only detected in one badger in our study, but had been previously reported not only in badgers $[10,20]$ but also in stoats and weasels $[31,121]$.

Although very commonly observed in our study, endoparasites seem to be of minor clinical relevance, in agreement with previous studies which documented numerous parasite species in apparently healthy mustelids [19-21]. Nevertheless, they were identified as being the main etiological diagnosis in 19 animals in this study (Table 2). Furthermore, while gastrointestinal parasites were only occasionally associated with degenerative changes (mucosal hyperplasia) and/or inflammation, pulmonary parasites were commonly documented with associated inflammation. This reaction was mostly mild but as stated above, it may have predisposed the affected hosts to secondary bacterial infection.

\section{Amyloidosis}

Amyloidosis is a well-known and frequent disease entity in martens. Because the etiology is mostly unknown, it is often referred to as "idiopathic amyloidosis" and considered to be a metabolic disorder [29, 30, 52, 122]. The term amyloidosis refers to the accumulation of a misfolded protein called amyloid. Two types of amyloidosis are distinguished in animals: AA- (or secondary amyloidosis) and non-AA amyloidosis. AA amyloidosis is the most common type and is related to chronic inflammation. Non-AA amyloidosis includes different forms, determined by the biochemical nature of the accumulating proteins. Among them, AL amyloidosis (or primary amyloidosis) is the least common form; the amyloid 
proteins are derived from immunoglobulin light chains $[123,124]$. AA and non-AA amyloidosis are characterized by the same pathological picture; Congo red staining with potassium permanganate pretreatment is required to distinguish them on histopathology [56]. In our material there was no association between amyloidosis and chronic infections, and amyloidosis appeared to be a primary pathological process. However, this and previous studies have demonstrated both AA and AL amyloidosis in martens [29, 30, 122, 125], suggesting that in martens amyloidosis cannot be attributed to a single cause. Genetics has been proposed to play a role in black footed ferrets [30] and stone martens [126], however, evidence of the transmissibility of the amyloid protein has been recently shown in laboratory animals $[127,128]$. It has also been hypothesized that amyloidosis may be secondary to Aleutian disease (AD) [129] in a case presenting with increased lymphoid reaction, hypergammaglobulinemia, glomerulonephritis, periportal hepatitis and vasculitis, which are features potentially caused by AD [73, 130-134]. Exposure to AD parvovirus has been shown by serological methods in captive and free-ranging mustelids in several European countries $[13-15,17,18]$ but so far similar investigations have not been performed in free-ranging mustelids in Switzerland. Since AD is known to be associated with meningoencephalitis, this disease should also be considered to be one of the differentials in the mustelids of this study, in which CNS inflammation was recorded but no etiological diagnosis was achieved.

Amyloidosis was commonly associated with behavioral changes in martens. Since the brain of the affected animals has only rarely been investigated histologically, it is not possible to assess the existence of amyloid deposits in this organ. However, this was not found in the samples we investigated, and non-specific behavioral changes may have been induced by the effects of systemic disease in the absence of CNS lesions.

\section{Other lesions}

We repeatedly observed oral lesions involving the teeth in badgers. Dental problems are well known in this species, especially in old individuals, and may be related to severe dental wear resulting from species-specific foraging behavior, such as the habit of digging into the ground to search for one of the badgers' favorite prey, earthworms [133, 134]. This might also explain the pneumoconiosis, which was more common in badgers than martens in our study.

\section{Conclusion}

Infectious diseases were common in mustelids from Switzerland during the whole study period, but their etiology varied over time. Strong similarities were noticed between disease occurrence in mustelids and the disease patterns found in red foxes: Rabies was frequently reported in mustelids prior to eradication in 1997, CD was often diagnosed beginning with the nationwide epidemic in 2009, and sarcoptic mange was sporadically observed for the past 15 years. This suggests pathogen transmission from foxes to other carnivores. Other noteworthy diseases diagnosed over the whole study period included bacterial infections mainly due to Streptococcus sp. and helminthiasis, as well as a few cases of hepatozoonosis, toxoplasmosis, aspergillosis and histoplasmosis. Overall, lung pathologies of infectious origin were very common, in agreement with former observations [31]. We also documented numerous differences between badgers and martens regarding disease etiology, frequency of disease occurrence and the type of lesions for the same disease. Importantly, we found no indication that mustelids currently play a role as reservoir for zoonotic pathogens in Switzerland. These data can serve as a baseline for future general health surveillance in Switzerland and for comparison with other European countries.

\section{Abbreviations \\ CD: Canine distemper; CDV: Canine distemper virus; CNS: Central nervous system; FIWI: Centre for Fish and Wildlife Health; IFA: Immunofluorescence assay; IHC: Immunohistochemistry; PCR: Polymerase chain reaction; RNA: Ribonucleic acid; RT: Respiratory tract; RT-PCR: Reverse transcription polymerase chain reaction}

\section{Acknowledgements}

Many thanks go to all persons and institutions who contributed to developing and maintaining the wildlife health surveillance program at the University of Bern during the past 50 years, in particular Michel Schmitt who shared precious information on old cases, Nadia Robert, Willy Meier t, Helmut Segner (FIWI), Bruno Gottstein (Institute of Parasitology) and Reto Zanoni (Swiss Rabies Centre); all staff involved in the diagnostic work; and all field partners who submitted animals or samples. Simon Capt (Centre de Cartographie de la Faune, Neuchâtel, Switzerland) provided information about the distribution and population size of mustelids in Switzerland. The authors also acknowledge the Federal Office for the Environment and the Federal Food Safety and Veterinary Office for the mandate of general wildlife health surveillance.

\section{Funding}

The author(s) received no specific funding for this work. Data collection was performed in the framework of the mandate for general wildlife health surveillance attributed by the Federal Office for the Environment and the Federal Food Safety and Veterinary Office.

\section{Availability of data and materials}

All relevant data supporting the conclusions of this study are presented in the article. Raw data may be obtained from the corresponding author on reasonable request.

\section{Authors' contributions}

EA contributed to data collection, digitalized all necropsy reports, performed the retrospective molecular and histopathological investigations, carried out the data analysis and drafted the manuscript. FCO contributed to data collection and supervised the molecular and histopathological retrospective evaluation of the cases. JW, JF and CF contributed to data collection. MPRD designed and coordinated the study, contributed to data collection and data analysis, and drafted the manuscript. All authors read and approved the final manuscript.

\section{Ethics approval and consent to participate}

This study did not involve purposeful killing of animals. All samples originated from dead wildlife (found dead in the field, legally shot because of severe 
debilitation). According to the legislation of Switzerland (922.0 hunting law and 455 animal protection law, including legislation on animal experimentation; www.admin.ch) and the Principality of Liechtenstein (www.gesetze.li), no ethical approval or permit for animal experimentation was required.

\section{Competing interests}

The authors declare that they have no competing interests.

\section{Publisher's Note}

Springer Nature remains neutral with regard to jurisdictional claims in published maps and institutional affiliations.

\section{Author details Switzerland. \\ Received: 10 March 2017 Accepted: 11 May 2018 \\ Published online: 19 June 2018}

${ }^{1}$ Centre for Fish and Wildlife Health (FIWI), Vetsuisse Faculty, University of Bern, Länggassstrasse 122, Postfach, 3001 Bern, Switzerland. ${ }^{2}$ Institute of Veterinary Bacteriology, Vetsuisse Faculty, University of Bern, Länggassstrasse 122, Postfach, 3001 Bern, Switzerland. Institute of Parasitology, Vetsuisse Faculty, University of Bern, Länggassstrasse 122, Postfach, 3001 Bern,

\section{References}

1. Musteliden HJ. Säugetiere Schweiz Verbreit. Biol. Ökol. Basel: DSAN und Birkhäuser; 1995. p. 367-402.

2. The IUCN red list of threatened species. http://www.iucnredlist.org/ (2016-3). Accessed 13 Feb 2017

3. Young J. Movement patterns of two New Zealand mustelids : implications for predator pest management. Lincoln University; 1998. https:// researcharchive.lincoln.ac.nz/handle/10182/2464. Accessed 13 Feb 2017.

4. Gallagher J, Clifton-Hadley RS. Tuberculosis in badgers; a review of the disease and its significance for other animals. Res Vet Sci. 2000;69:203-17.

5. Holmala K, Kauhala K. Ecology of wildlife rabies in Europe. Mammal Rev. 2006:36:17-36.

6. Delahay RJ, Cheeseman CL, Clifton-Hadley RS. Wildlife disease reservoirs: the epidemiology of Mycobacterium bovis infection in the European badger (Meles meles) and other British mammals. Tuberculosis. 2001;81:43-9.

7. Donnelly CA, Wei G, Johnston WT, Cox DR, Woodroffe R, Bourne FJ, et al. Impacts of widespread badger culling on cattle tuberculosis: concluding analyses from a large-scale field trial. Int J Infect Dis. 2007;11:300-8.

8. Frölich K, Czupalla O, Haas L, Hentschke J, Dedek J, Fickel J. Epizootiological investigations of canine distemper virus in free-ranging carnivores from Germany. Vet Microbiol. 2000;74:283-92

9. Pavlacik L, Celer V, Koubek P, Literak I. Prevalence of canine distemper virus in wild mustelids in the Czech Republic and a case of canine distemper in young stone martens. Vet Med (Praha). 2007;52:69-73.

10. Origgi FC, Plattet $P$, Sattler U, Robert N, Casaubon J, Mavrot F, et al. Emergence of canine distemper virus strains with modified molecular signature and enhanced neuronal tropism leading to high mortality in wild carnivores. Vet Pathol. 2012;49:913-29.

11. Beineke A, Baumgärtner W, Wohlsein P. Cross-species transmission of canine distemper virus - an update. One Health. 2015;1:49-59.

12. Williams ES, Thome ET, Appel MJG, Belitsky DW. Canine distemper in blackfooted ferrets (Mustela nigripes) from Wyoming. J Wildl Dis. 1988;24:385-98.

13. Mañas S, Ceña JC, Ruiz-Olmo J, Palazón S, Domingo M, Wolfinbarger JB, et al. Aleutian mink disease parvovirus in wild riparian carnivores in Spain. J Wildl Dis. 2001:37:138-44.

14. Fournier-Chambrillon C, Aasted B, Perrot A, Pontier D, Sauvage F, Artois M, et al. Antibodies to aleutian mink disease parvovirus in free-ranging European mink (Mustela lutreola) and other small carnivores from southwestern France. J Wildl Dis. 2004;40:394-402.

15. Hammer AS, Dietz HH, Hamilton-Dutoit S. Immunohistochemical detection of 3 viral infections in paraffin-embedded tissue from mink (Mustela vison): a tissue-microarray-based study. Can J Vet Res. 2007;71:8-13.

16. Farid $\mathrm{AH}$. Aleutian mink disease virus in furbearing mammals in Nova Scotia, Canada. Acta Vet Scand. 2013:55:10.

17. Leimann A, Knuuttila A, Maran T, Vapalahti O, Saarma U. Molecular epidemiology of Aleutian mink disease virus (AMDV) in Estonia, and a global phylogeny of AMDV. Virus Res. 2015;199:56-61.
18. Persson $\mathrm{S}$, Jensen $\mathrm{TH}$, Blomström A-L, Appelberg MT, Magnusson U. Aleutian mink disease virus in free-ranging mink from Sweden. PLoS One. 2015;10:e0122194.

19. Segovia J-M, Torres J, Miquel J, Sospedra E, Guerrero R, Feliu C. Analysis of helminth communities of the pine marten, Martes martes, in Spain: mainland and insular data. Acta Parasitol. 2007;52:156-64.

20. Torres J, Miquel J, Motjé M. Helminth parasites of the Eurasian badger (Meles meles L.) in Spain: a biogeographic approach. Parasitol Res. 2001;87:259-63.

21. Torres J, Miquel J, Fournier P, Fournier-Chambrillon C, Liberge M, Fons R, et al. Helminth communities of the autochthonous mustelids Mustela lutreola and M. putorius and the introduced Mustela vison in South-Western France. J Helminthol. 2008;82:349-55.

22. Loos-Frank B, Zeyhle E. The intestinal helminths of the red fox and some other carnivores in Southwest Germany. Z Parasitenkd. 1982;67:99-113.

23. Seville RS, Addison EM. Nongastrointestinal helminths in marten (Martes americana) from Ontario, Canada. J Wildl Dis. 1995:31:529-33.

24. Yanai T, Tomita A, Masegi T, Ishikawa K, Iwasaki T, Yamazoe K, et al. Histopathologic features of naturally occurring hepatozoonosis in wild martens (Martes melampus) in Japan. J Wildl Dis. 1995;31:233-7.

25. Wohlsein P, Bauder B, Kuttin E, Kaufman L, Seeliger F, von Keyserling M. Histoplasmosis in two badgers (Meles meles) in Northern Germany. Deut Tierarztl Woch. 2001:108:273-6.

26. Eisenberg T, Seeger H, Kasuga T, Eskens U, Sauerwald C, Kaim U. Detection and characterization of Histoplasma capsulatum in a German badger (Meles meles) by ITS sequencing and multilocus sequencing analysis. Med Mycol. 2013;51:337-44.

27. Bauder B, Kübber-Heiss A, Steineck T, Kuttin ES, Kaufman L. Granulomatous skin lesions due to histoplasmosis in a badger (Meles meles) in Austria. Med Mycol. 2000;38:249-53.

28. Jensen HE, Bloch B, Henriksen P, Dietz HH, Schønheyder H, Kaufman L. Disseminated histoplasmosis in a badger (Meles meles) in Denmark. APMIS Acta Pathol Microbiol Immunol Scand. 1992;100:586-92.

29. Scaglione FE, Mignone W, Ferrero E, Poggi M, Biolatti B, Bollo E. Systemic AL amyloidosis in a beech Marten (Martes foina). Res Vet Sci. 2013;95:569-71.

30. Garner MM, Raymond JT, O'Brien TD, Nordhausen RW, Russell WC. Amyloidosis in the black-footed ferret (Mustela nigripes). J Zoo Wildl Med Off Publ Am Assoc Zoo Vet. 2007;38:32-41.

31. Simpson VR, Tomlinson AJ, Stevenson K, McLuckie JA, Benavides J, Dagleish MP. A post-mortem study of respiratory disease in small mustelids in southWest England. BMC Vet Res. 2016;12:72.

32. Mörner T, Obendorf D, Artois M, Woodford M. Surveillance and monitoring of wildlife diseases. Rev Sci Tech Int Off Epizoot. 21:67-76.

33. Kuiken T, Ryser-Degiorgis MP, Gavier-Widén D, Gortázar C. Establishing a European network for wildlife health surveillance. Rev. Sci. Tech. Int. Off. Epizoot. 2011;30:755-61.

34. Ryser-Degiorgis M-P, Pewsner M, Angst C. Joining the dots - understanding the complex interplay between the values we place on wildlife, biodiversity conservation, human and animal health: a review. Schweiz Arch Tierheilkd. 2015:157:243-53.

35. Philippa J, Fournier-Chambrillon C, Fournier P, Schaftenaar W, van de Bildt $M$, van Herweijnen $R$, et al. Serologic survey for selected viral pathogens in free-ranging endangered European mink (Mustela lutreola) and other mustelids from South-Western France. J Wildl Dis. 2008:44:791-801.

36. Ryser-Degiorgis M-P. Wildlife health investigations: needs, challenges and recommendations. BMC Vet Res. 2013:9:223.

37. Je C. Diagnostic pathology of selected diseases in wildlife. Rev Sci Tech Int Off Epizoot. 2002;21:77-89.

38. Info Fauna/Verbreitungskarten Tierarten. https:/lepus.unine.ch/carto/index php? nuesp=70745\&rivieres=on\&lacs=on\&hillsh=on\&data=on\&year=2000. Accessed 11 Feb 2017

39. KORA: Marderartige. http://www.kora.ch/index.php?id=74\&L=0\%29. Accessed 13 Feb 2017

40. Magazin «umwelt»1/2014 - Den Wald gestalten. issuu. 2014. https://issuu. com/bundesamt-fuer-umwelt-bafu/docs/den-wald-gestalten?reader3=1. Accessed 13 Feb 2017

41. Ryser-Degiorgis M-P, Segner H. National competence center for wildlife diseases in Switzerland: mandate, development and current strategies. Schweiz Arch Tierheilkd. 2015;157:255-66.

42. Burri K. Schweiz Suisse Svizzera Svizra. Geografische Betrachtungen ab 7. Schuljahr. Zürich: Lehrtmittelverlag; 1998.

43. Pewsner M, Origgi FC, Frey J, Ryser-Degiorgis M-P. Assessing fifty years of general health surveillance of roe deer in Switzerland: a retrospective analysis of necropsy reports. PLoS One. 2017;12:e0170338. 
44. International Commision on Trichinellosis (ICT). Essential QA standards for digestion testing - Part_2_final___Digestion_assasy__final__7Feb2012.pdf. Int. Commision Trichinellosis ICT. 2012. Available from: http://www. trichinellosis.org/uploads/Part_2_final____Digestion_assasy_final__ 7Feb2012.pdf. Accessed 22 Feb 2017.

45. Eckert J. Veterinärmedizinische Parasitologie. 4th ed. Hamburg: Paul Parey; 1992.

46. Deplazes P, Eckert J, Samson-Himmelstjerna G von, Zahner H. Lehrbuch der Parasitologie für die Tiermedizin. Stuttgart: Enke; 2012.

47. Bornstein S, Zakrisson G, Thebo P. Clinical picture and antibody response to experimental Sarcoptes scabiei var. vulpes infection in red foxes (Vulpes vulpes). Acta Vet Scand. 1995;36:509-19.

48. Sloss M, Kemp R. Veterinary clinical parasitology. 5th ed. Ames lowa: lowa State University; 1978.

49. Bollo E, Zurbriggen A, Vandevelde M, Fankhauser R. Canine distemper virus clearance in chronic inflammatory demyelination. Acta Neuropathol (Berl). 1986:72:69-73.

50. Burgisser H, Fankhauser R, Kaplan W, Klingler K, Scholer HJ. Mykose bei einem Dachs in der Schweiz: histologisch Histoplasmose. Pathobiology. 1961;24:794-802.

51. Kox LF, Kuijper S, Kolk AH. Early diagnosis of tuberculous meningitis by polymerase chain reaction. Neurology. 1995;45:2228-32.

52. Geisel O. Die Krankheiten von Steinmarder Martes foina (Erxleben, 1777) und Baummarder Martes martes (Linné, 1758) unter besonderer Berücksichtigung pathologischer Organbefunde. Berlin und Hamburg: Paul Parey Scientific Publishers; 1992.

53. Open-Source-Geographisches-Informationsystem. http://www.osgeo.org. Accessed 13 Feb 2017

54. Swiss Geoportal. geo.admin.ch. https://map.geo.admin.ch. Accessed 13 Feb 2017.

55. Sieber V, Robert N, Schybli M, Sager H, Miserez R, Engels M, et al. Causes of mortality and diseases in farmed deer in Switzerland. Vet Med Int. 2010;2010:e684924.

56. van Rijswijk MH, van Heusden CW. The potassium permanganate method. A reliable method for differentiating amyloid AA from other forms of amyloid in routine laboratory practice. Am J Pathol. 1979;97:43-58.

57. Statistical Software / Sample Size Software | NCSS. https://www.ncss.com/. Accessed 13 Feb 2017

58. Origgi FC, Wu N, Pilo P. Francisella tularensis infection in a stone marten (Martes foina) without classic pathological lesions consistent with tularemia. J Vet Diagn Investig Off Publ Am Assoc Vet Lab Diagn Inc. 2013;25:519-21.

59. Capt S, Marchesi P. Monitoring der Kleinmusteliden in der Schweiz. Neuchâtel, Switzerland: Centre Suisse de Cartographie de la Faune (CSCF); 2012.

60. Wobeser G, Wobeser AG. Carcass disappearance and estimation of mortality in a simulated die-off of small birds. J Wildl Dis. 1992;28:548-54.

61. Stallknecht DE. Impediments to wildlife disease surveillance, research, and diagnostics. Curr Top Microbiol Immunol. 2007;315:445-61.

62. Schreitmüller W. Beobachtungen an Mardern und Iltissen in Gefangenschaft. Z Säugetierkd. 1941;301-3.

63. Palmer D, Ossent P, Waldvogel A, Weilenmann R. Staupe-Encephalitis beim Steinmarder (Martes foina, Erxleben, 1777) in der Schweiz. Schweiz Arch Tierheilkd. 1983;125:525-36.

64. Herr J, Schley L, Roper TJ. Socio-spatial organization of urban stone martens. J Zool. 2009;277:54-62

65. Breitenmoser U, Müller U, Kappeler A, Zanoni RG. Die Endphase der Tollwut in der Schweiz. Schweiz Arch Tierheilk. 2000;147:447-53.

66. Zanoni RG, Kappeler A, Müller UM, Müller C, Wandeler Al, Breitenmoser U. Rabies-free status of Switzerland following 30 years of rabies in foxes. Schweiz Arch Tierheilkd. 2000;142:423-9.

67. Amstislavsky S, Ternovskaya Y. Reproduction in mustelids. Anim Reprod Sci. 2000;60-61:571-81.

68. Johnson DDP, MacDonald DW, Dickman AJ. An analysis and review of models of the sociobiology of the Mustelidae. Mammal Rev. 2000;30:171-96.

69. Eidgenössische Jagdstatistik. https://www.uzh.ch/wild/ssl-dir/jagdstatistik/ ?page=home\#. Accessed 13 Feb 2017.

70. Gavier-Widen D, Meredith A, Duff JP. Infectious diseases of wild mammals and birds in Europe. West Sussex: Wiley Blackwell; 2012.

71. van Moll P, Alldinger S, Baumgärtner W, Adami M. Distemper in wild carnivores: an epidemiological, histological and immunocytochemical study. Vet Microbiol. 1995;44:193-9.

72. Sekulin K, Hafner-Marx A, Kolodziejek J, Janik D, Schmidt P, Nowotny N. Emergence of canine distemper in Bavarian wildlife associated with a specific amino acid exchange in the haemagglutinin protein. Vet J. 2011;187:399-401.
73. Nouvellet P, Donnelly CA, Nardi MD, Rhodes CJ, Benedictis PD, Citterio C, et al. Rabies and canine distemper virus epidemics in the red fox population of northern Italy (2006-2010). PLoS One. 2013;8:e61588.

74. Hammer AS, Dietz HH, Andersen TH, Nielsen L, Blixenkrone-Moeller M. Distemper virus as a cause of central nervous disease and death in badgers (Meles meles) in Denmark. Vet Rec. 2004;154:527-30.

75. Wiener DJ, Welle MM, Origgi FC. Cutaneous lesions associated with dual infection caused by canine distemper virus and orthopoxvirus in a domestic cat. Vet Dermatol. 2013;24:543-e130.

76. Origgi FC, Sattler U, Pilo P, Waldvogel AS. Fatal combined infection with canine distemper virus and orthopoxvirus in a group of Asian marmots (Marmota caudata). Vet Pathol. 2013;50:914-20.

77. Zhao J, Shi N, Sun Y, Martella V, Nikolin V, Zhu C, et al. Pathogenesis of canine distemper virus in experimentally infected raccoon dogs, foxes, and minks. Antivir Res. 2015;122:1-11.

78. Krakowka S. Mechanisms of in vitro immunosuppression in canine distemper virus infection. J Clin Lab Immunol. 1982:8:187-96.

79. Svitek N, Gerhauser I, Goncalves C, Grabski E, Döring M, Kalinke U, et al. Morbillivirus control of the interferon response: relevance of STAT2 and mda5 but not STAT1 for canine distemper virus virulence in ferrets. J Virol. 2014;88:2941-50.

80. Duff JP, Hunt B. Courtship and mortality in foxes (Vulpes vulpes). Vet. Rec. 1995;136:367.

81. Chalmers G, McLean J, Hunter DB, Brash M, Slavic D, Pearl DL, et al. Staphylococcus spp., Streptococcus canis, and Arcanobacterium phocae of healthy Canadian farmed mink and mink with pododermatitis. Can J Vet Res. 2015;79:129-35.

82. Hirsh DC, Zee YC. Vet. Microbiol. Immunol. Malden, Massachusetts: Blackwell Science; 1999. p. 115-25.

83. Simpson VR. Patterns and significance of bite wounds in Eurasian otters (Lutra lutra) in southern and south-West England. Vet. Rec. 2006;158:113-9.

84. Polkanov A. Aspects of the biology, ecology and captive breeding of stoats. Wellington, New Zealand: Dept Conservation, Conservation Advisory Science Notes; 2000.

85. Maxie G. Bronchopneumonia. St. Louis: Elsevier Health Sciences; 2015. p. 506-8.

86. Besser TE, Frances Cassirer E, Highland MA, Wolff $P$, Justice-Allen A, Mansfield K, et al. Bighorn sheep pneumonia: sorting out the cause of a polymicrobial disease. Prev Vet Med. 2013;108:85-93.

87. Murphy D, Gormley E, Costello E, O'Meara D, Corner LAL. The prevalence and distribution of Mycobacterium bovis infection in European badgers (Meles meles) as determined by enhanced post mortem examination and bacteriological culture. Res Vet Sci. 2010;88:1-5.

88. Payne A, Boschiroli ML, Gueneau E, Moyen JL, Rambaud T, Dufour B, et al. Bovine tuberculosis in "Eurasian" badgers (Meles meles) in France. Eur J Wildl Res. 2013;59:331-9.

89. Gortazar C, Vicente J, Boadella M, Ballesteros C, Galindo RC, Garrido J, et al. Progress in the control of bovine tuberculosis in Spanish wildlife. Vet Microbiol. 2011;151:170-8.

90. Schöning JM, Cerny N, Prohaska S, Wittenbrink MM, Smith NH, Bloemberg G, et al. Surveillance of bovine tuberculosis and risk estimation of a future reservoir formation in wildlife in Switzerland and Liechtenstein. PLoS One. 2013;8:e54253.

91. Fink M, Schleicher C, Gonano M, Prodinger WM, Pacciarini M, Glawischnig W, et al. Red deer as maintenance host for bovine tuberculosis, alpine region. Emerg Infect Dis. 2015;21:464.

92. Bouvier G, Burgisser R, Sweitzer R. Tuberculose chez un chamois. Schweiz Arch Tierheilk. 1951;93:689.

93. Ryser-Degiorgis M-P, Capt S. Occurrence of sarcoptic mange in free-ranging wildlife in Switzerland. Mamm Biol. 2003;38:57-8.

94. Pence D, Ueckermann E. Sarcoptic mange in wildlife. Rev Sci Tech Int Off Epizoot. 2002;21:385-98.

95. Nimmervoll H, Hoby S, Robert N, Lommano E, Welle M, Ryser-Degiorgis M-P. Pathology of sarcoptic mange in red foxes (Vulpes vulpes): macroscopic and histologic characterization of three disease stages. J Wildl Dis. 2013;49:91-102.

96. Ryser-Degiorgis M-P, Ryser A, Bacciarini LN, Angst C, Gottstein B, Janovsky $M$, et al. Notoedric and sarcoptic mange in free-ranging lynx from Switzerland. J Wildl Dis. 2002;38:228-32.

97. Holt G, Berg C. Sarcoptic mange in red foxes and other wild carnivores in Norway. Nor Veterinærtidsskrift. 1990;102:427-32.

98. Balestrieri A, Remonti L, Ferrari N, Ferrari A, Valvo TL, Robetto S, et al. Sarcoptic mange in wild carnivores and its co-occurrence with parasitic helminths in the western Italian alps. Eur J Wildl Res. 2006;52:196-201. 
99. Emmons CW. Histoplasmosis: animal reservoirs and other sources in nature of pathogenic fungus, Histoplasma. Am J Public Health Nations Health. 1950;40:436-40.

100. Grosse G, Staib F, Rapp J, Rang H, Heise W, Kaufma L. Pathological and epidemiological aspects of skin lesions in histoplasmosis: observations in an AIDS patient and badgers outside endemic areas of histoplasmosis. Zentralblatt Bakteriol. 1997;285:531-9.

101. Delahay RJ, Walker NJ, Forrester GJ, Harmsen B, Riordan P, Macdonald DW, et al. Demographic correlates of bite wounding in Eurasian badgers, Meles meles L., in stable and perturbed populations. Anim Behav. 2006;71:1047-55.

102. Zschille J, Stier N, Roth M. Radio tagging American mink (Mustela vison) - experience with collar and intraperitoneal-implanted transmitters. Eur J Wildl Res. 2008;54:263-8.

103. Bartlett G, Smith W, Dominik C, Batac F, Dodd E, Byrne BA, et al. Prevalence, pathology, and risk factors associated with Streptococcus phocae infection in southern sea otters (Enhydra lutris nereis), 2004-10. J Wildl Dis. 2015;52:1-9.

104. Powell R. Mustelid spacing patterns: variations on a theme by Mustela. Z Tierpsychol. 1979;50:153-65.

105. Jones GW, Neal C, Harris EA. The helminth parasites of the badger (Meles meles) in Cornwall. Mammal Rev. 1980;10:163-4.

106. Anwar MA, Newman C, MacDonald DW, Woolhouse ME, Kelly DW. Coccidiosis in the European badger (Meles meles) from England, an epidemiological study. Parasitology. 2000;120(Pt 3):255-60.

107. Newman C, Macdonald DW, Anwar MA. Coccidiosis in the European badger, Meles meles in Wytham woods: infection and consequences for growth and survival. Parasitology. 2001;123:133-42.

108. Bouvier G, Hörning B. Reports of trichinella for the years 1965-1968 from Switzerland. Schweiz Arch Tierheilk. 1968;110:622-4.

109. Hoberg EP, Aubry KB, Brittell JD. Helminth parasitism in martens (Martes americana) and ermines (Mustela erminea) from Washington, with comments on the distribution of Trichinella spiralis. J Wildl Dis. 1990;26:447-52.

110. Oltean M, Kalmár Z, Kiss BJ, Marinov M, Vasile A, Sándor AD, et al. European mustelids occupying pristine wetlands in the Danube Delta are infected with trichinella likely derived from domesticated swine. J Wildl Dis. 2014;50:972-5.

111. Takeuchi-Storm N, Al-Sabi MNS, Thamsborg SM, Enemark HL. Alaria alata Mesocercariae among feral cats and badgers, Denmark. Emerg Infect Dis. 2015;21:1872-4.

112. Tadros W, Laarman JJ. Muscular sarcosporidiosis in the common European weasel, Mustela nivalis. Z Parasitenkd Berl Ger. 1979;58:195-200.

113. Burns R, Williams ES, OToole D, Dubey JP. Toxoplasma gondii infections in captive black-footed ferrets (Mustela nigripes), 1992-1998: clinical signs, serology, pathology, and prevention. J Wildl Dis. 2003;39:787-97.

114. Fuentes MV, Galán-Puchades MT, Malone JB. Short report: a new case report of human Mesocestoides infection in the United States. Am J Trop Med Hyg. 2003;68:566-7.

115. Barsanti JA, Jones BD, Bailey WS, Knipling GD. Diagnosis and treatment of peritonitis caused by a larval cestode Mesocestoides spp., in a dog. Cornell Vet. 1979;69:45-53.

116. Priemer J, Lux E. Atriotaenia incisa (Cestoda), a parasite of the badger, Meles meles, and the raccoon, Procyon lotor, in Brandenburg, Germany. Can J Zool. 1994;72:1848-53.

117. Nijsse R, Mughini-Gras L, Wagenaar JA, Ploeger HW. Coprophagy in dogs interferes in the diagnosis of parasitic infections by faecal examination. Vet Parasitol. 2014;204:304-9

118. van Soest RWM, van der Land J, van Bree PJH. Skrjabingylus nasicola (Nematoda) in skulls of Mustela erminea and Mustela nivalis (Mammalia) from the Netherlands. Beaufortia 1972;20:85-97.

119. King CM. The nematode Skrjabingylus nasicola (Metastrongyloidea) in mustelids: a new record for New Zealand. N Z J Zool. 1974;1:501-2.

120. Santi SA, Parker GH, Schaffner NP, Capodagli L, Persinger MA. Prevalence, intensity, and geographic distribution of sinus worm (Skrjabingylus nasicola) infection in mink (Mustela vison) of Central Ontario. Can J Zool. 2006;84:1011-8.

121. Spratt DM. Species of Angiostrongylus (Nematoda: Metastrongyloidea) in wildlife: a review. Int J Parasitol Parasites Wildl. 2015;4:178-89.

122. Geisel O. Die Krankheiten von Steinmarder Martes foina (Erxleben, 1777) und Baummarder Martes martes (Linné, 1758). Unter besonderer Berücksichtigung pathologischer Organbefunde. Berlin, Hamburg: Paul Parey; 2007.

123. Woldemeskel M. A concise review of amyloidosis in animals. Vet Med Int. 2012;2012:427296.
124. Maxie G. Amyloidosis. Jubb Kennedy palmers Pathol. Domest. Anim. 6th ed. St. Louis: Elsevier Health Sciences; 2015. p. 413-5.

125. Wien TN, Sørby R, Omtvedt LA, Landsverk T, Husby G. Kinetics of glycosaminoglycan deposition in splenic AA amyloidosis induced in mink Scand J Immunol. 2004;60:600-8.

126. Linke RP, Hol PR, Gruys E, Geisel O, Nathrath WBJ, Trautwein G. Immunohistochemical identification and crossreactions of amyloid-a fibril protein in man and eleven other species. J Comp Pathol. 1984;94:339-56.

127. Murakami T, Ishiguro N, Higuchi K. Transmission of systemic AA amyloidosis in animals. Vet Pathol. 2014;51:363-71.

128. Tjernberg LO, Rising A, Johansson J, Jaudzems K, Westermark P. Transmissible amyloid. J Intern Med. 2016;280:153-63.

129. Wells G, Keymer F, Barnett K. Suspected Aleutian disease in a wild otter (Lutra lutra). Vet Rec. 1989;125:232-5.

130. Alexandersen S. Pathogenesis of disease caused by Aleutian mink disease parvovirus. APMIS Suppl. 1990;14:1-32.

131. Steinel A, Parrish CR, Bloom ME, Truyen U. Parvovirus infections in wild carnivores. J Wildl Dis. 2001;37:594-607.

132. Sánchez-Migallón Guzmán D, Carvajal A, García-Marín JF, Ferreras MC, Pérez $V$, Mitchell M, et al. Aleutian disease serology, protein electrophoresis, and pathology of the European mink (Mustela lutreola) from Navarra, Spain. J Zoo Wildl Med. 2008:39:305-13.

133. Hancox M. Field age determination in the European badger. Rev Ecologie. 1988:399-404.

134. Lüps $P$, Roper TJ. Tooth size in the European badger (Meles meles) with special reference to sexual dimorphism, diet and intraspecific aggression. Acta Theriol (Warsz). 1988;33:21-33.

\section{Ready to submit your research? Choose BMC and benefit from:}

- fast, convenient online submission

- thorough peer review by experienced researchers in your field

- rapid publication on acceptance

- support for research data, including large and complex data types

- gold Open Access which fosters wider collaboration and increased citations

- maximum visibility for your research: over $100 \mathrm{M}$ website views per year

At BMC, research is always in progress.

Learn more biomedcentral.com/submissions 